\title{
Review \\ Formation and Growth of Intermetallic Compounds in Lead-Free Solder Joints: A Review
}

\author{
Mohd Izrul Izwan Ramli 1,2 ${ }^{D}$, Mohd Arif Anuar Mohd Salleh 1,2,*, Mohd Mustafa Al Bakri Abdullah 1,2,*, \\ Nur Syahirah Mohamad Zaimi 1,2, Andrei Victor Sandu 3,4,5 D, Petrica Vizureanu 3,4,*iD, Adam Rylski 6 \\ and Siti Farahnabilah Muhd Amli ${ }^{1,2}$
}

1 Faculty of Chemical Engineering Technology, Universiti Malaysia Perlis (UniMAP), Kangar 02600, Malaysia; izrulizwan@unimap.edu.my (M.I.I.R.); syahirahzaimi25@gmail.com (N.S.M.Z.); sitifarahnabilah@outlook.com (S.F.M.A.)

2 Geopolymer \& Green Technology, Center of Excellence (CEGeoGTech), Universiti Malaysia Perlis (UniMAP), Kangar 02600, Malaysia

3 Faculty of Materials Science and Engineering, Gheorghe Asachi Technical University of Iasi, D. Mangeron 41, 700050 Iasi, Romania; sav@tuiasi.ro

4 Romanian Inventors Forum, St. P. Movila 3, 700089 Iasi, Romania

5 National Institute for Research and Development in Environmental Protection INCDPM, Splaiul Independentei 294, 060031 Bucharest, Romania

6 Institute of Materials Science and Engineering, Faculty of Mechanical Engineering, Lodz University of Technology, Stefanowskiego 1/15, 90-924 Lodz, Poland; adam.rylski@p.lodz.pl

* Correspondence: arifanuar@unimap.edu.my (M.A.A.M.S.); mustafa_albakri@unimap.edu.my (M.M.A.B.A.); peviz@tuiasi.ro (P.V.)

check for updates

Citation: Ramli, M.I.I.; Salleh, M.A.A.M.; Abdullah, M.M.A.B.; Zaimi, N.S.M.; Sandu, A.V.;

Vizureanu, P.; Rylski, A.; Amli, S.F.M.

Formation and Growth of

Intermetallic Compounds in

Lead-Free Solder Joints: A Review.

Materials 2022, 15, 1451. https://

doi.org/10.3390/ma15041451

Academic Editor: Chih Chen

Received: 22 December 2021

Accepted: 10 February 2022

Published: 15 February 2022

Publisher's Note: MDPI stays neutral with regard to jurisdictional claims in published maps and institutional affiliations.

Copyright: (c) 2022 by the authors. Licensee MDPI, Basel, Switzerland. This article is an open access article distributed under the terms and conditions of the Creative Commons Attribution (CC BY) license (https:// creativecommons.org/licenses/by/ $4.0 /)$.

\begin{abstract}
Recently, research into the factors that influence the formation and growth of intermetallic compounds (IMCs) layer in lead-free solders has piqued interest, as IMCs play an important role in solder joints. The reliability of solder joints is critical to the long-term performance of electronic products. One of the most important factors which are known to influence solder joint reliability is the intermetallic compound (IMC) layer formed between the solder and the substrate. Although the formation of an IMC layer signifies good bonding between the solder and substrate, its main disadvantage is due to its brittle nature. This paper reviews the formation and growth of IMCs in lead-free solder joints detailing the effect of alloying additions, surface finishes, aging time, aging temperature and solder volume. The formation and growth of the brittle IMCs were significantly affected by these factors and could be possibly controlled. This review may be used as a basis in understanding the major factors effecting the IMC formation and growth and relating it to the reliability of solder joints.
\end{abstract}

Keywords: intermetallic compound; alloying; surface finish; solder alloy

\section{Introduction}

Tin-lead $(\mathrm{Sn}-\mathrm{Pb})$ solder has been widely used as an interconnecting material for many years. Nevertheless, owing to health and environmental concerns, Pb usage in electrical equipment is prohibited [1,2]. The European Union's (EU) directive on the Restriction of Hazardous Substances in Electrical and Electronic Equipment (RoHS) confirmed that the $\mathrm{Pb}$ usage in customer hardware is prohibited. Due to differences in their physical and mechanical characteristics, lead-free solder alloys cannot easily replace conventional lead-containing solder alloys. This is because, in comparison to $\mathrm{Sn}-\mathrm{Pb}$ solder, lead-free solder systems usually create a thicker intermetallic compound (IMC) layer. Intermetallic phase generation in an electronic joint is normally undesirable due to the fact intermetallic phases are often brittle and more prone to crack growth.

IMCs are generated when two or more metallic elements come together to form a new phase having its own characteristics, crystal structure, and composition. The IMC 
phase could form in bulk solder during soldering application and at the interface between substrate and solder. Moreover, the solder alloy reacts with the substrate during the soldering process, forming an interfacial IMC layer at the interface. Its development has a substantial impact on the solder joint's reliability [3]. In soldering, a thin coating of interfacial intermetallic is recommended to establish effective metallurgical bonding at the interface.

Nonetheless, owing to their brittle and hard character, excessive interfacial intermetallic compound development in solder joints is detrimental [4]. Therefore, the IMCs thickness layer, which defines the solder joint's reliability and strength, is needed. A small amount of IMCs can be studied to signify that the solder joint has formed an excellent connection [5]. As a result, a persistent effort has been made to comprehend the mechanism of the interfacial interactions, which includes the intermetallic growth and formation at bulk as well as substrate/solder interfaces. Understanding the morphology, characteristics, and growth behaviour of intermetallic phases is critical for understanding solder connection reliability. Throughout the last several decades, researchers have examined the interaction between substrate and solder during soldering. For example, a recent study found that the expansion of the IMCs layer degrades the solder joint's reliability.

This research examines the factors that govern the formation of lead-free solder IMCs with minor alloying elements and several types of surface finish to understand the performance of the interfacial IMCs layer. We also discuss the various studies on the effect of aging temperature as well as the volume of solder on IMC properties.

\section{Effect of Alloying Additions}

\subsection{Formation and Growth of IMC in the Bulk Solder}

The intermetallic phase might develop in the bulk solder as the main part of the eutectic phase and interfacial IMCs in a lead-free solder alloy. During the soldering process, some metal substrates dissolve in the molten solder, forming an interfacial IMCs layer at the metal-solder interface by a process known as dissolution within the solder and substrate. As the $\mathrm{Cu}$ level rises, the main $\mathrm{Cu}_{6} \mathrm{Sn}_{5}$ intermetallic species may be observed in the solder joint bulk. The $\mathrm{Cu}_{6} \mathrm{Sn}_{5}$ intermetallic is a key component of $\mathrm{Pb}$-free solder joints' microstructure. The microstructure of eutectic Sn-Cu alloy may be changed with the addition of a small amount of a given alloying element to the bulk microstructure of Sn-0.7Cu. Besides, the formation of intermetallics in solder alloy could be predicted by referring to the phase diagram, as depicted in Figure 1 [6].

Moreover, Nogita et al. [7] observed a considerable change in the nucleation pattern as well as behaviour of the $\mathrm{Sn}-\mathrm{Cu}_{6} \mathrm{Sn}_{5}$ and $\mathrm{Sn}$ when up to $1000 \mathrm{ppm}$ of $\mathrm{Ni}$ was added to $\mathrm{Sn}-0.7 \mathrm{Cu}$ solder. In the absence of $\mathrm{Ni}, \mathrm{Sn}-0.7 \mathrm{Cu}$ shows a solidification process that progressed from the edge to the bulk solder alloy centre, a phenomenon is known as the 'wall mechanism. In addition, the macroscopic development at the interface changed by adding Ni to this alloy, yielding a solid development from vast nucleation sites across the melting alloy. Gourlay et al. [8] also examined the impact of adding Ni to the Sn-Cu solder alloy, claiming that the transition in the solidification mode occurred at a concentration of 0-300 ppm Ni. The alloy's microstructure was unaffected by raising the Ni concentration. Nogita et al. [9] introduced a small quantity of $\mathrm{Ni}$ to an $\mathrm{Sn}-\mathrm{Cu} \mathrm{Pb}$-free solder and discovered that the IMCs layer in the Sn-Cu-Ni solder cracked less than the Ni state. In that work, synchrotron XRD was utilised to establish the Ni role in solder alloys, which is to stabilise the hexagonal $(\mathrm{Cu}, \mathrm{Ni})_{6} \mathrm{Sn}_{5}$. The nucleation and development of the main $\mathrm{Cu}_{6} \mathrm{Sn}_{5}$ intermetallic were considerably affected when $0.05 \mathrm{wt}$.\% $\mathrm{Ni}$ was added to Sn-0.7Cu [10]. They also suggested that primary $\mathrm{Cu}_{6} \mathrm{Sn}_{5}$ developed at higher temperatures, which was smaller and more common in $\mathrm{Sn}-0.7 \mathrm{Cu}-0.05 \mathrm{Ni} / \mathrm{Cu}$ joints compared to $\mathrm{Sn}-0.7 \mathrm{Cu} / \mathrm{Cu}$ joints. Besides, Ventura et al. [11] investigated $\mathrm{Sn}-0.7 \mathrm{Cu}-\mathrm{Ni}$ alloys with $0-1000 \mathrm{ppm} \mathrm{Ni}$ and discovered that $\mathrm{Ni}$ inhibits the production of $\beta$-Sn, lowering the volumetric proportion of the main $\beta$-Sn phase. Ni raises the interfacial energy among the eutectic phases, causing the eutectic to become irregular. Micro-additions of $\mathrm{Ni}$ can be used to control thtectic cellular prevalence 
development compared to a eutectic dendritic matrix in the Sn-0.7 wt.\% Cu solder alloy, as described by Silva et al. [12]. As a result, small amounts of $\mathrm{Ni}$ (500-1000 ppm of Ni) appear to stabilise cell development, and if greater cooling rates are enforced, the creation of a dendritic array is achievable. The addition of $\mathrm{Ni}$ into $\mathrm{Sn}-\mathrm{Ag}$ has been studied by Gumaan et al. [13]. They reported that the addition of $\mathrm{Ni}$ has been refined the particle size of $\beta$-Sn. Moreover, with $0.3 \mathrm{wt} . \%$ of $\mathrm{Ni}$ and distribution of $\mathrm{Ag}_{3} \mathrm{Sn}$ offer the potential benefit such as high strength, good plasticity and good mechanical performance.

a)

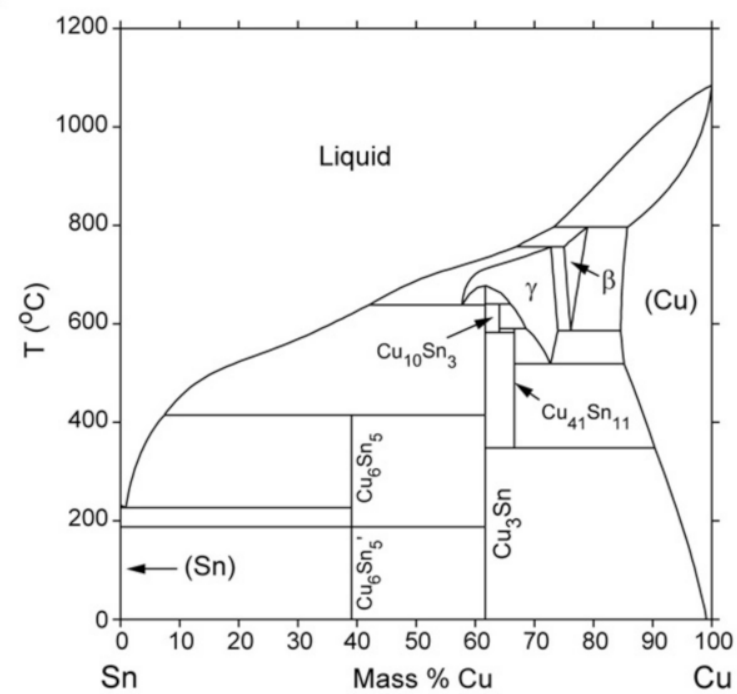

b)

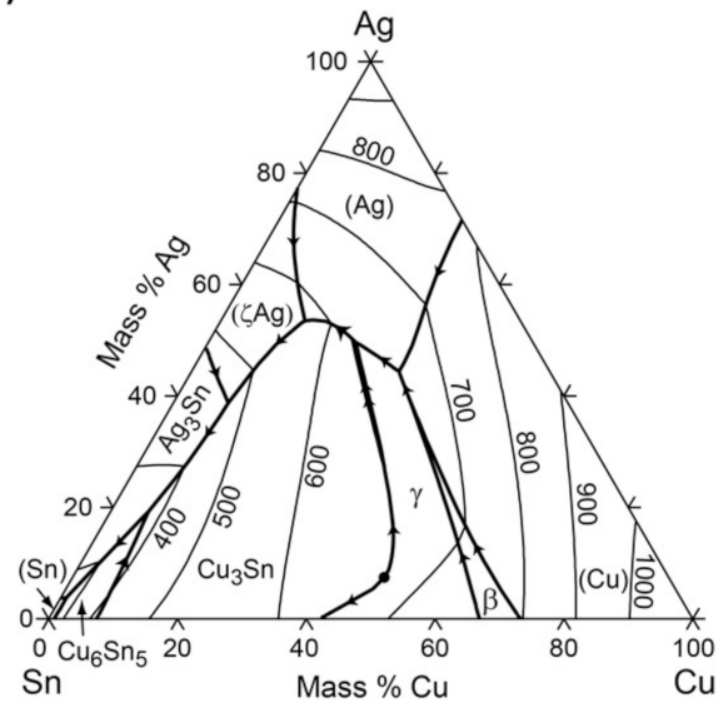

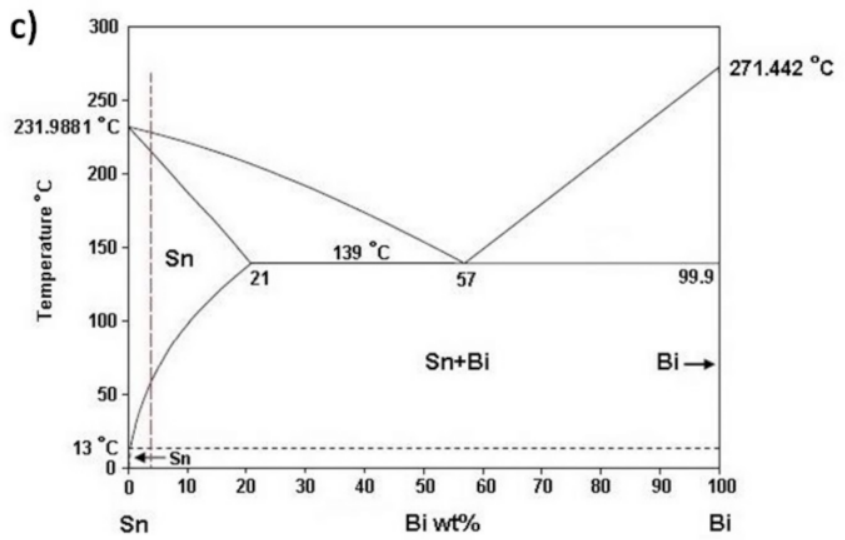

Figure 1. Phase diagram for (a) binary $\mathrm{Sn}-\mathrm{Cu},(\mathbf{b})$ ternary $\mathrm{Sn}-\mathrm{Ag}-\mathrm{Cu}$ and (c) binary Sn-Bi.

According to Xian et al. [14], the addition of $\mathrm{Al}$ to $\mathrm{Sn}-0.7 \mathrm{Cu}$ might be employed to regulate the main size $\mathrm{Cu}_{6} \mathrm{Sn}_{5}$ rods, as illustrated in Figure 2. They hypothesized that the addition of a small amount $\mathrm{Al}$ into $\mathrm{Sn}-0.7 \mathrm{Cu}$ solder alloy helps to reduce the $\mathrm{Cu}_{6} \mathrm{Sn}_{5}$ size while increasing the number of $\mathrm{Cu}_{6} \mathrm{Sn}_{5}$ particles per unit volume. In $\mathrm{Sn}-0.7 \mathrm{Cu} / \mathrm{Cu}$ and $\mathrm{Sn}$ $0.7 \mathrm{Cu}-0.05 \mathrm{Al} / \mathrm{Cu}$ joints, the overall proportion of $\mathrm{Cu}_{6} \mathrm{Sn}_{5}$ is comparable. Apart from that, using synchrotron radiation X-ray imaging, Wang et al. [15] examined the development of $\mathrm{Cu}_{6} \mathrm{Sn}_{5}$ on $\mathrm{Sn}-6.5 \mathrm{Cu}$. The growth behaviour of $\mathrm{Cu}_{6} \mathrm{Sn}_{5}$ at the $\mathrm{Sn} / \mathrm{Cu}$ interface during soldering processes has been studied using synchrotron radiation. The authors found that by adding $0.2 \mathrm{Al}$ to $\mathrm{Sn}-6.5 \mathrm{Cu}$ solder, the mean size of $\mathrm{Cu}_{6} \mathrm{Sn}_{5}$ was reduced compared to $\mathrm{Sn}-6.5 \mathrm{Cu}$ solder. This is due to the $\mathrm{Al}$ traces refinement on the $\mathrm{Cu}_{6} \mathrm{Sn}_{5}$ microstructures. The addition of $\mathrm{Al}$ interacted having $\mathrm{Cu}$ to create $\mathrm{Cu}-\mathrm{Al} \mathrm{IMCs}$, inhibiting the development of $\mathrm{Cu}_{6} \mathrm{Sn}_{5}$. The $\mathrm{Al}$ influence on the $\mathrm{Sn}-0.7 \mathrm{Cu}$ solder alloys microstructure was investigated by Yang et al. [16]. Al refines the $\mathrm{Sn}-\mathrm{Cu}$ solder alloy microstructure, according to the findings. Sn-Cu-Al solder alloy's IMCs ranged from $\mathrm{Cu}_{6} \mathrm{Sn}_{5}$ in $\mathrm{Sn}-\mathrm{Cu}-(0.01-0.025) \mathrm{Al}$ to 
$\mathrm{Al}_{2} \mathrm{Cu}$ in $\mathrm{Sn}-0.7 \mathrm{Cu}-(0.05-0.075) \mathrm{Al}$. With increasing $\mathrm{Al}$ concentration, the volume fraction of the eutectic and IMC rises. According to Ma et al. [17], adding the rare-earth (RE) element La to the Cu-Sn solder alloy decreased the thickness of the Cu-Sn IMC interface layer of solder joints. This implies that the addition of modest quantities of La can minimize the driving power of Cu-Sn IMC formation.
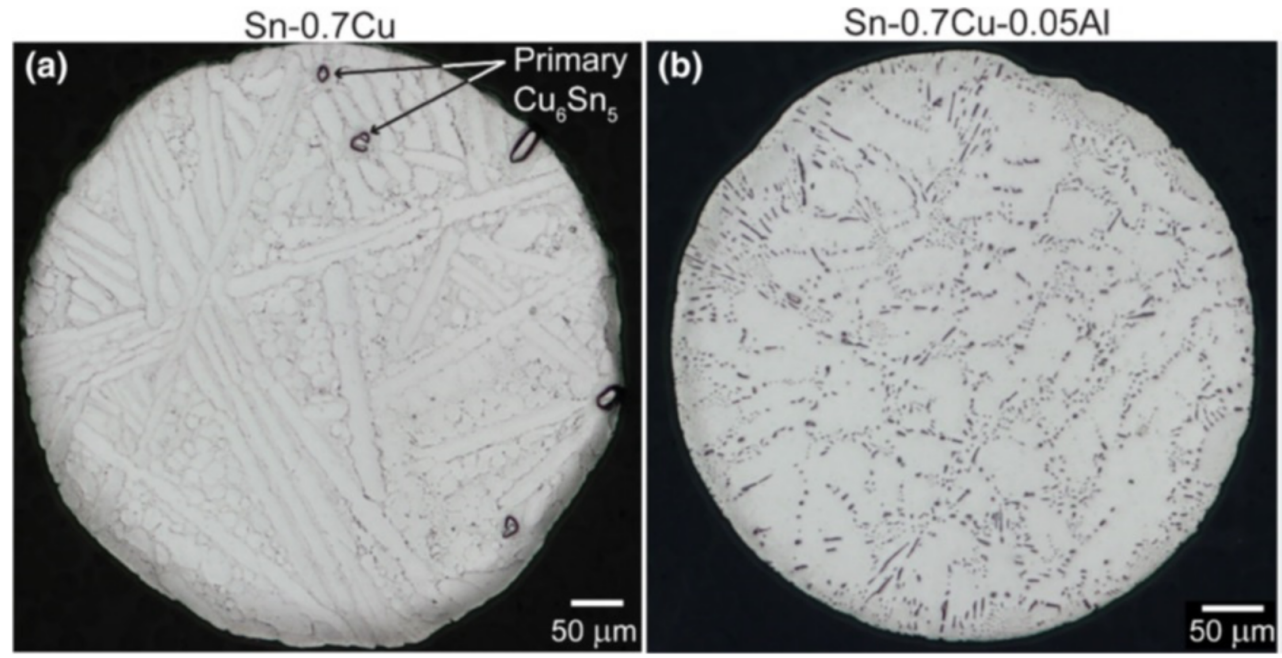

Figure 2. Microstructure images of (a) $\mathrm{Sn}-0.7 \mathrm{Cu},(\mathbf{b}) \mathrm{Sn}-0.7 \mathrm{Cu}-0.05 \mathrm{Al}[14]$.

Mcdonald et al. [18] also researched the effect of trace elements addition on the morphology and size of the primary $\mathrm{Cu}_{6} \mathrm{Sn}_{5}$ in $\mathrm{Sn}-4 \mathrm{wt} . \% \mathrm{Cu}$ alloy with and without the addition of $\mathrm{Ni}$. The investigation included additions of ppm of $\mathrm{Pb}, \mathrm{Ge}, \mathrm{Ag}$, as well as $\mathrm{Al}$. It was reported that $\mathrm{Al}$ influences the microstructure of the solder and refines the primary $\mathrm{Cu}_{6} \mathrm{Sn}_{5}$ size that occurs during primary solidification. They also claimed that the addition of $\mathrm{Al}$ increases the number of heterogeneous nuclei for $\mathrm{Cu}_{6} \mathrm{Sn}_{5}$. Reeve et al. [19] studied the $\mathrm{Al}$ growth in Sn-Ag-Cu and Sn-Cu. Every Al-modified alloy formed Cu-Al IMC particles having various phases and morphologies, according to the researchers. With rising $\mathrm{Al}$ concentration, a tendency of increased $\mathrm{Cu}-\mathrm{Al} \mathrm{IMC}$ volume percentage was discovered. This $\mathrm{Cu}-\mathrm{Al}$ IMC nucleation between solder alloys benefitted the strength of the solder BGA systems. Apart from that, grain refinement in these joints and $\mathrm{Cu}-\mathrm{Al}$ IMCs occurrence restrain the formation of a thermal fatigue crack. Small quantities of RE elements, primarily $\mathrm{La}$ and $\mathrm{Ce}$, were added to the $\mathrm{Sn}-0.7 \mathrm{Cu}$ solder alloy by $\mathrm{Wu}$ et al. [20]. Adding $0.5 \% \mathrm{RE}$ elements led to one-third to half of the $\beta$-Sn grains morphing into smaller $5-10 \mathrm{~m}$. Precisely, adding $0.25 \%$ RE elements resulted in one-third to half of the $\beta$-Sn grains transforming into smaller grains of 5-10 $\mu \mathrm{m}$. When $0.5 \%$ RE elements were added, the initial $\beta$-Sn grains were refined to the point where virtually all of them were $5-10 \mu \mathrm{m}$ in size, and the solidified microstructure became evenly distributed $\mathrm{Cu}_{6} \mathrm{Sn}_{5}$.

Apart from that, the $\mathrm{Zn}$ and $\mathrm{Ni}$ addition effect on $\mathrm{Sn}-0.7 \mathrm{Cu} / \mathrm{Cu}$ solder joints was studied by Zeng et al. [21]. The authors found that adding small quantities of Zn during solidification led to the production of a $\mathrm{Cu}-\mathrm{Zn}$ intermetallic in the interdendritic region. However, adding small $\mathrm{Ni}$ amounts entirely alters the solidification mode, yielding a eutectic microstructure. Via Ni addition, tiny particles of primary $(\mathrm{Cu}, \mathrm{Ni})_{6} \mathrm{Sn}_{5}$ intermetallic formed ahead of the solidification front. The microstructure was modified by microalloying $\mathrm{Zn}$ and $\mathrm{Ni}$, resulting in a more continuous, stable, and fine-grained interfacial $\mathrm{Cu}_{6} \mathrm{Sn}_{5}$ intermetallic while also reducing $\mathrm{Cu}_{3} \mathrm{Sn}$ development. $\mathrm{Cu}_{6} \mathrm{Sn}_{5}$ 's polymorphic phase change is inhibited by $\mathrm{Ni}$ and $\mathrm{Zn}$, which are homogeneously dispersed in the interfacial $\mathrm{Cu}_{6} \mathrm{Sn}_{5}$. In addition, Zeng et al. [22] improved the Sn-0.7Cu-0.15Zn solder's solidification. During solidification, $\mathrm{Zn}$ has been shown to dramatically decrease the solidification range of $\beta$-Sn in an $\mathrm{Sn}-0.7 \mathrm{Cu}$ alloy. As a result, $\mathrm{Zn}$ might aid in the nucleation of $\beta$-Sn, which could impact phase selection during the near-eutectic alloys formation grown at low temperatures. 


\subsection{Formation and Growth of IMC at the Solder-Substrate Interface}

For an interfacial IMC, the composition of the interfacial intermetallic is dictated by the combination of the metal surface and metal used. Interfacial intermetallic is necessary for every solder joint, and its reaction defines the overall solder joint's reliability. During the reflow process between the substrate and the solder, a thin layer of interfacial intermetallic is generated. The $\mathrm{Cu}$ dissolution rate into the liquid, as well as the chemical reaction between $\mathrm{Cu}$ and $\mathrm{Sn}$, are the key parameters that affect the thickness and form of the reaction layer. Tin-nickel (Sn-Ni) and tin-copper (Sn-Cu) are the two most frequent forms of interfacial intermetallic. The first phase of $\mathrm{Cu}-\mathrm{Sn}$ interfacial intermetallic is formed nearest to the $\mathrm{Cu}$ interface and called " $\varepsilon$-phase" $\mathrm{Cu}_{3} \mathrm{Sn}$ intermetallic. Another phase of $\mathrm{Cu}-\mathrm{Sn}$, called " $\eta$-phase" $\mathrm{Cu}_{6} \mathrm{Sn}_{5}$, will form on top of the $\mathrm{Cu}_{3} \mathrm{Sn}$ intermetallic. The interfacial intermetallic formed between $\mathrm{Ni}$ and $\mathrm{Sn}$ at a much slower rate relative to the $\mathrm{Cu}-\mathrm{Sn}$ intermetallic and is called the " $\delta$-phase" $\mathrm{Ni}_{3} \mathrm{Sn}_{4}$ intermetallic. The $\mathrm{Sn}-\mathrm{Ni}$ intermetallic is brittler than the $\mathrm{Sn}-\mathrm{Cu}$ intermetallic $[23,24]$.

The impact of alloying elements on the interfacial intermetallic has been studied by several researchers. These studies focus on the trace alloying elements added to the solder that can influence the formation and growth of IMCs $[25,26]$. Among alloying elements, $\mathrm{Ni}$ possesses the greatest impact on IMC growth. It reduces the thickness of $\mathrm{Cu}_{3} \mathrm{Sn}$ and the overall IMC layer $[27,28]$. Dissolution of Ni may affect the IMC layer on the $\mathrm{Cu}^{\prime}$ s surface. The $\mathrm{Cu}$ atom in $\mathrm{Cu}_{6} \mathrm{Sn}_{5}$ can be substituted with $\mathrm{Ni}$ atom, which changes the composition to $(\mathrm{Cu}, \mathrm{Ni})_{6} \mathrm{Sn}_{5}$. Nagy et al. [29] elucidated the role of $\mathrm{Ni}$ in $(\mathrm{Cu}, \mathrm{Ni})_{6} \mathrm{Sn}_{5}$ IMC in Sn-Cu-Ni. They discovered that increasing the Ni content causes the $\mathrm{Cu}_{6} \mathrm{Sn}_{5}$ intermetallic's lattice parameters a and c to decrease. The Ni addition to the lattice structure of $\mathrm{Sn}-0.7 \mathrm{Cu}$ causes a reflection shift at higher angles and a small change in the reflection intensity. Increased Ni concentration causes a reduction in mean crystallite size, according to these findings. The IMCs layer thickness for $\mathrm{Sn}-0.7 \mathrm{Cu}$ solder was larger compared to Sn-0.7wt.\%Cu-0.3wt.\%Ni solder, according to Rizvi et al. [30]. Besides, Nishikawa et al. [31] examined how an IMC formed and grew at the interface between a $\mathrm{Cu}$ pad and $\mathrm{Sn}-\mathrm{Ag}(-$ Co) solders. $(\mathrm{Cu}, \mathrm{Co})_{6} \mathrm{Sn}_{5}$ and $\mathrm{Cu}_{6} \mathrm{Sn}_{5}$ are expected to be the intermetallic phases of the two regions. The replacement of $\mathrm{Co}$ atoms for $\mathrm{Cu}$ atoms in binary compounds with $\mathrm{Sn}$ is anticipated to generate a $(\mathrm{Cu}, \mathrm{Co})_{6} \mathrm{Sn}_{5}$ phase. They discovered that adding $\mathrm{Co}$ to the $\mathrm{Sn}$-Ag solder had a significant impact on the IMC development and growth at the interface. Also, Sn-Ag-Co solders have an IMC thickness of about three times compared to binary $\mathrm{Sn}-\mathrm{Ag}$ solders. The solders also had identical total IMC thicknesses after $1008 \mathrm{~h}$ of aging. The Sn-Ag-Co solder joint's pull strength was insignificantly distinct compared to the binary Sn-Ag solder joint.

Moreover, according to Laurila, Vuorinen and Kivilahti [23], the rate of IMC growth and formation is influenced by the Ni concentration. The authors found that adding more wt.\% Ni caused the intermetallic layer to expand faster. Therefore, the $\mathrm{Cu}_{6} \mathrm{Sn}_{5}$ compound was also created in the $\mathrm{Sn}-0.7 \mathrm{Cu}$ solder. Meanwhile, the $\left(\mathrm{Cu}, \mathrm{Ni}_{6} \mathrm{Sn}_{5}\right.$ compound was formed in the $\mathrm{Sn}-0.7 \mathrm{Cu}-0.05 \mathrm{Ni}$ solder. The $\mathrm{Ni}$ addition to the $\mathrm{Sn}-\mathrm{Cu}$ solder also reduced the production of cracks in the $\mathrm{Cu}_{6} \mathrm{Sn}_{5}$ IMC at the solder-substrate interface. Hence, as demonstrated in Figure 3, the stabilisation of the hexagonal $\mathrm{Cu}_{6} \mathrm{Sn}_{5}$ in Ni addition prevents volume variations that may trigger the cracking process [24]. The $\mathrm{Sn}-\mathrm{Ag}$-Cu with $\mathrm{Au} / \mathrm{Ni} / \mathrm{Cu}$ substrate was previously discovered by Yen et al. [32], who determined that the $\mathrm{Ge}$ and Ni addition did not affect the interfacial reactions. However, Ge segregation on the solder ball surface improved the anti-oxidation properties of the solder. Moreover, Wang and Shen [33] also studied the impact of $\mathrm{Ni}$ on the interfacial reactions between $\mathrm{Ni}$ substrate and $\mathrm{Sn}-\mathrm{Cu}$ solders. Thus, the authors discovered that when the Ni concentration in the reaction phase grain of $\mathrm{Cu}_{6} \mathrm{Sn}_{5}$ rises, the morphology of the reaction phase grain of $\mathrm{Cu}_{6} \mathrm{Sn}_{5}$ shifts from a rod-like form to a faceted structure. 

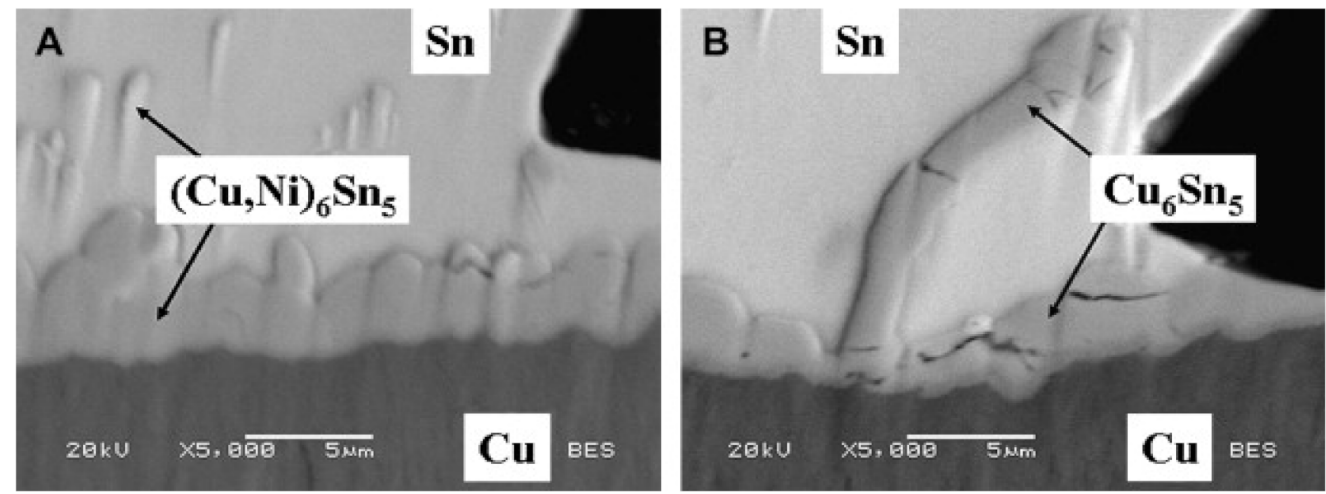

Figure 3. Typical cross-sectioned of solder joints; (A) Sn-0.7Cu-0.05Ni solder and (B) Sn-0.7Cu solder [24].

Nishikawa, Komatsu and Takemoto [31] examined how an IMC formed and grew at the interface between a $\mathrm{Cu}$ pad and $\mathrm{Sn}$-Ag-Co solders. Here, $(\mathrm{Cu}, \mathrm{Co})_{6} \mathrm{Sn}_{5}$ and $\mathrm{Cu}_{6} \mathrm{Sn}_{5}$ are expected to be the intermetallic phases of the two regions. Moreover, the $(\mathrm{Cu}, \mathrm{Co})_{6} \mathrm{Sn}_{5}$ phase arises when $\mathrm{Co}$ is substituted for $\mathrm{Cu}$ in binary compounds containing $\mathrm{Sn}$. Moreover, adding Co to the Sn-Ag solder had a substantial impact on the development and expansion of the IMC at the interface, according to the findings. As a result, the thickness of IMC layer in Sn-Ag-Co solder will be increased about three times compared to binary Sn-Ag solders. The solder link's pull strength made with the Sn-Ag-Co solder was similar with respect to the binary Sn-Ag solder. Apart from that, Zeng, McDonald, Gu, Terada, Uesugi, Yasuda and Nogita [21] explained the effects of $\mathrm{Zn}$ and $\mathrm{Ni}$ in $\mathrm{Sn}-0.7 \mathrm{Cu} / \mathrm{Cu}$ solder joints. Also, it demonstrates that slight $\mathrm{Zn}$ additions cause the creation of a $\mathrm{Cu}-\mathrm{Zn}$ intermetallic in the interdendritic region during solidification.

Meanwhile, a slight quantity of $\mathrm{Ni}$ entirely alters the solidification mode and results in a eutectic microstructure. Small particles of primary $(\mathrm{Cu}, \mathrm{Ni})_{6} \mathrm{Sn}_{5}$ intermetallic form ahead of the solidification front when $\mathrm{Ni}$ is introduced. Microalloying $\mathrm{Zn}$ and $\mathrm{Ni}$ at the same time refine the microstructure, yielding a more continuous, fine-grained, as well as stable $\mathrm{Cu}_{6} \mathrm{Sn}_{5}$ intermetallic that inhibits $\mathrm{Cu}_{3} \mathrm{Sn}$ development. $\mathrm{Cu}_{6} \mathrm{Sn}_{5}$ 's polymorphic phase change is inhibited by $\mathrm{Zn}$ and $\mathrm{Ni}$, which are homogeneously dispersed in the interfacial $\mathrm{Cu}_{6} \mathrm{Sn}_{5}$. Apart from that, Zeng, Mcdonald, Gourlay, Uesugi, Terada, Yasuda and Nogita [22] investigated the solidification of $\mathrm{Sn}-0.7 \mathrm{Cu}-0.15 \mathrm{Zn}$ solder. It is widely known that during solidification, $\mathrm{Zn}$ may greatly limit the solidification range of $\beta-\mathrm{Sn}$ in an $\mathrm{Sn}-0.7 \mathrm{Cu}$ alloy. As a result, $\mathrm{Zn}$ may aid in the nucleation of $\beta$-Sn, which might impact phase selection during the development of undercooled near-eutectic alloys.

Furthermore, Zou and Zhang [34] investigated the impact of adding Zn to Sn-4Ag interacting with an Ag substrate. The authors discovered that increment in the Zn content in the Sn-4Ag solder causes the Ag-Sn IMC to become dominant at the interface, with the exception of the thinner Ag-Zn IMC. During the interfacial reaction with the increment of $\mathrm{Zn}$ concentration, Ag-Zn IMCs developed at the interface. Hence, the IMC shape changed from continuous IMC layers to discontinuous and loose IMC layers when the $\mathrm{Zn}$ concentration was increased. In addition, Chan et al. [35] created a novel solder alloy by mixing $0.3 \mathrm{wt} . \% \mathrm{Zn}$ nanoparticles into $\mathrm{Sn}-3.8 \mathrm{Ag}-0.7 \mathrm{Cu}$ solder, resulting in thinner $\left(\mathrm{Cu}_{3} \mathrm{Sn}\right.$ and $\mathrm{Cu}_{6} \mathrm{Sn}_{5}$ ) IMCs. When the extra percentage was increased to $0.8 \mathrm{wt} . \%$, a new IMC layer $\left(\mathrm{Cu}_{5} \mathrm{Zn}_{8}\right)$ was produced, increasing the overall IMC. On the other hand, Zhang et al. [36] found that adding $0.8 \% \mathrm{Zn}$ to $\mathrm{Sn}-3.8 \mathrm{Ag}-0.7 \mathrm{Cu}$ solder slowed the formation of Sn-Cu IMC in the liquid/solid-state process owing to $\mathrm{Zn}$ atom accumulation at the interface.

In recent decades, $\mathrm{Sn}-\mathrm{Ag}$-Cu solder alloys became an option in substituting the lead solder for various applications due to their favourable thermal-mechanical fatigue as well as low melting temperature [37]. Moreover, adding alloying elements has a major effect on 
suppressing intermetallic phases' growth. In summary, the addition of alloying elements on $\mathrm{Sn}-\mathrm{Ag}-\mathrm{Cu}$ has been summarized by Zeng et al. [38].

Shalaby [39] investigated the impact of adding $\mathrm{Ni}, \mathrm{Cr}$, and In to $\mathrm{Sn}-0.7 \mathrm{Cu}$ and discovered that the introduction of $\mathrm{Ni}, \mathrm{Cr}$, and In suppressed the development of eutectic quickly solidified $\mathrm{Sn}-0.7 \mathrm{Cu}$ alloy. Inside the Sn-rich phase, the synthesis of novel IMCs, which include $\mathrm{In}_{3} \mathrm{Sn}, \mathrm{Cu}_{6} \mathrm{Sn}_{5}, \mathrm{Cu}_{10} \mathrm{Sn}_{3}$, and $\mathrm{Ni}-\mathrm{Sn}$, is more dispersed evenly. Li et al. [40] investigated the inclusion of indium to an $\mathrm{Sn}-0.7 \mathrm{Cu}-0.2 \mathrm{Ni} / \mathrm{Cu}$ soldered joint. They reveal that eutectic $\mathrm{Cu}_{6} \mathrm{Sn}_{5}$ with a thickness of around $32.4 \mu \mathrm{m}$, and minor quantities of $\mathrm{Sn}$ are formed. The IMC layer thickness steadily grows as the amount of indium added rises. The IMC layer thickness grows from 36.2 to $55.6 \mu \mathrm{m}$ when the indium inclusion is increased from 0.1 to $0.3 \mathrm{wt} . \%$. Subsequently, Lee et al. [41] asserted that thermal aging of the $\mathrm{Sn}-\mathrm{Ag}-\mathrm{Sb}$ lead-free solder system causes the interfacial $\mathrm{Cu}_{6} \mathrm{Sn}_{5}$ compounds layer to shift to $\mathrm{Cu}_{6}(\mathrm{Sn}$, In) 5 . Li et al. [42] investigated the introduction of phosphorus to $\mathrm{Sn}-0.7 \mathrm{Cu}$. Also, the IMC thickness in the $\mathrm{Sn}-0.7 \mathrm{Cu}-0.005 \mathrm{P}$ solder joint appears to expand quicker compared to the Sn-0.7Cu solder joint.

During creep-fatigue testing, the abundant IMCs may be the weakest part in the solder joint, and the crack may spread over the IMCs. They hypothesized that adding phosphorus to $\mathrm{Sn}-0.7 \mathrm{Cu}$ solder reduces its creep-fatigue life, probably due to increased gap production. The vacancies in the solder joint might contribute to crack starting or propagation areas. Also, Koo and Lee [39] reported the incorporation of $\mathrm{Al}$ to $\mathrm{Sn}-0.5 \mathrm{Cu}$. Other than that, the $\mathrm{Al}$ inclusion promoted the creation of the $\mathrm{Cu}-\mathrm{Al}\left(\delta-\mathrm{Cu}_{33} \mathrm{Al}_{17}\right) \mathrm{IMC}$ in the $\mathrm{Sn}-0.5 \mathrm{Cu}-$ based solder matrix that successfully prevented the production of eutectic $\beta-\mathrm{Sn}+\mathrm{Cu}_{6} \mathrm{Sn}_{5}$ networks. The inclusion of $\mathrm{Al}$ disrupted the development of eutectic $\beta-\mathrm{Sn}+\mathrm{Cu}-\mathrm{Sn} \mathrm{IMC}$ networks, and the quantity of $\mathrm{Cu}_{6} \mathrm{Sn}_{5}$ reduced as the quantity of $\mathrm{Al}$ was increased. Adding 0.02 and $0.2 \mathrm{wt} . \% \mathrm{Al}$ to $\mathrm{Sn}-\mathrm{Cu}$ reduced $\mathrm{Cu}_{6} \mathrm{Sn}_{5}$ nucleation undercooling and increased the quantity of $\mathrm{Cu}_{6} \mathrm{Sn}_{5}$ grains, according to Xian et al. [43]. Ma et al. [44] revealed that a Co-reinforced Sn-3.0Ag-0.5Cu composite solder inhibited IMC layer development. They hypothesized that the Co particles can bind $\mathrm{Sn}$ and $\mathrm{Cu}$ to produce $\mathrm{Co}-\mathrm{Sn}$ or $\mathrm{Co}-\mathrm{Cu}$ IMC near the interfacial layer, preventing $\mathrm{Cu}$ from being accessible for IMC layer creation and slowing their development rate. A minor Ga introduction, on the other hand, can stop IMC from growing. According to Luo et al. [45], Ga inclusion can lower the activity of Sn, hence suppressing the formation of $\mathrm{Cu}_{6} \mathrm{Sn}_{5}$. Gao et al. [46] explored how the introduction of $\mathrm{Nd}$ affects the evolution of the IMCs layer. The explanation for this might be due to the production of an Sn-Nd combination, which slows the $\mathrm{Cu}_{6} \mathrm{Sn}_{5} \mathrm{IMC}$ growth. The Sn-Ag$\mathrm{Cu}$ lead-free solder's IMC thickness was diminished when a small trace quantity of RE elements La was introduced [47].

In their research, Zhang et al. [48] discovered that adding $0.03 \% \mathrm{Ce}$ to $\mathrm{Sn}-\mathrm{Ag}$-Cu alloy decreased the IMC layer thickness and improved the solder joint strength. The morphology of IMC produced at the $\mathrm{Sn}-\mathrm{Ag}-\mathrm{Cu} / \mathrm{Cu}$ and $\mathrm{Sn}-\mathrm{Ag}-\mathrm{Cu}-\mathrm{Ce} / \mathrm{Cu}$ interfaces eventually altered from scallop-like to planar-like, according to the researchers. In comparison to the $\mathrm{Sn}-\mathrm{Ag}$ $\mathrm{Cu}-\mathrm{Ce} / \mathrm{Cu}$ system, the $\mathrm{Sn}-\mathrm{Ag}-\mathrm{Cu} / \mathrm{Cu}$ IMC grew at a faster pace. The Fe impact on the IMC growth kinetics during liquid state interfacial reaction has been examined, and Fe inclusion efficiently retards the interfacial $\mathrm{Cu}_{6} \mathrm{Sn}_{5}$ and $\mathrm{Cu}_{3} \mathrm{Sn}$ layer growth. The overall thickness of IMC Sn-Ag-Cu-Fe composite solder was comparable to $\mathrm{Sn}-\mathrm{Ag}$-Cu excluding Fe particles [49]. Haseeb and Leng [50,51] investigated the influence of Mo and Co nanoparticles on interfacial IMC between $\mathrm{Cu}$ substrate and $\mathrm{Sn}-3.8 \mathrm{Ag}-0.7 \mathrm{Cu}$ solder. They discovered that adding Mo nanoparticles to $\mathrm{Cu}_{6} \mathrm{Sn}_{5}$ interfacial IMC can reduce its thickness. The introduction of $\mathrm{Co}$, on the other hand, can promote $\mathrm{Cu}_{6} \mathrm{Sn}_{5}$ development while suppressing $\mathrm{Cu}_{3} \mathrm{Sn}$ growth. As a result, they propose dissolving Co nanoparticles in $\mathrm{Cu}_{6} \mathrm{Sn}_{5}$ to alter the IMC compositions. As a result presented and analyzed above, it could be concluded that the adding of an alloying element will influence the IMC thickness and the IMC interfacial formation. Table 1 outlines the influence of minor alloying elements on IMC in the existing lead-free solder research database. 
Table 1. Influence of minor alloying elements to the IMC thickness in lead-free solder joints.

\begin{tabular}{cccc}
\hline Solder Alloy & Element & Thickness of IMC & Ref \\
\hline Sn-Ag-0.5Cu & $\mathrm{Fe}$ & Unchanged & {$[49]$} \\
Sn-3.0Ag-0.5Cu & $\mathrm{Sb}$ & Unchanged & {$[38]$} \\
Sn-3.0Ag-0.5Cu & $\mathrm{Fe}$ & Unchanged & {$[38]$} \\
Sn-3.0Ag-0.5Cu & $\mathrm{In}$ & Unchanged & {$[38]$} \\
Sn-3.0Ag-0.5Cu & $\mathrm{Ge}$ & Increase & {$[38]$} \\
Sn-3.9Ag-0.7Cu & $\mathrm{La}$ & Decrease & {$[47]$} \\
Sn-3.8Ag-0.7Cu & $\mathrm{Nd}$ & Decrease & {$[46]$} \\
\hline Sn-2.8Ag-0.5Cu & $\mathrm{Bi}$ & Unchanged & {$[52]$} \\
\hline & $\mathrm{Mo}$ & Decrease & {$[50]$} \\
Sn-3.8Ag-0.7Cu & $\mathrm{Co}$ & Decrease & {$[51]$} \\
& $\mathrm{Zn}$ & Decrease & {$[35]$} \\
\hline $\mathrm{Sn}-0.5 \mathrm{Ag}-0.7 \mathrm{Cu}$ & $\mathrm{Ga}$ & Decrease & {$[45]$} \\
$\mathrm{Sn}-3.0 \mathrm{Ag}-0.5 \mathrm{Cu}$ & $\mathrm{Co}$ & Decrease & {$[44]$} \\
$\mathrm{Sn}-3.8 \mathrm{Ag}-0.7 \mathrm{Cu}$ & $\mathrm{Zn}$ & Decrease & {$[36]$} \\
$\mathrm{Sn}-4 \mathrm{Ag}$ & $\mathrm{Zn}$ & Decrease & {$[34]$} \\
$\mathrm{Sn}-0.7 \mathrm{Cu}$ & $\mathrm{Al}$ & Decrease & {$[43]$} \\
$\mathrm{Sn}-0.5 \mathrm{Cu}$ & $\mathrm{Al}$ & Decrease & {$[53]$} \\
$\mathrm{Sn}-0.7 \mathrm{Cu}$ & $\mathrm{P}$ & Increased & {$[42]$} \\
$\mathrm{Sn}-0.7 \mathrm{Cu}$ & $\mathrm{Cn}$ & Decrease & {$[39]$} \\
$\mathrm{Sn}-0.7 \mathrm{Cu}$ & $\mathrm{Ni}$ & Decrease & {$[26]$} \\
$\mathrm{Sn}-0.7 \mathrm{Cu}$ & $\mathrm{Ni}$ & Decrease & {$[30]$} \\
$\mathrm{Sn}-\mathrm{Cu}$ & $\mathrm{Ni}$ & Decrease & {$[24]$} \\
$\mathrm{Sn}-0.7 \mathrm{Cu}-0.05 \mathrm{Ni}$ & $\mathrm{Bi}$ & Unchanged & {$[54]$} \\
$\mathrm{Sn}-0.7 \mathrm{Cu}-0.2 \mathrm{Ni}$ & $\mathrm{In}$ & Increased & \\
\hline & & & \\
\hline & & &
\end{tabular}

\section{Effect of Surface Finish}

The choice of a suitable surface finish is crucial because the IMC layer is considerably affected by the surface finishes material during soldering. The thickness and composition of IMCs also greatly affected by surface finish layers. To overcome the pace of growth between the solder and the substrate, several surface finishes are applied. $\mathrm{Cu}$ is the most widely utilized metal, given its excellent solderability. Even though $\mathrm{Cu}$ is the most frequent substrate for solder joints, various options work best. Electroless nickel immersion gold (ENIG), electroless nickel gold (NiAu), organic solderability preservative (OSP), and immersion $\mathrm{Ag}(\mathrm{ImAg})$ are the most prevalent surface finishes. The IMC layer is generally entirely formed on one of three metal surfaces: electroless nickel, electrolytic nickel or copper. The IMC layer formed on copper when soldering consists of $\mathrm{Cu}_{6} \mathrm{Sn}_{5}$ (close to the bulk solder). Also, $\mathrm{Cu}_{3} \mathrm{Sn}$ (close to the copper substrate) IMCs layer forms at the $\mathrm{Cu}_{6} \mathrm{Sn}_{5} / \mathrm{Cu}$ interface under high temperatures. Although the IMC layer generated on electrolytic nickel is $\mathrm{Ni}_{3} \mathrm{Sn}_{4}$, there is another intermetallic form present in this surface finish. The IMC layer generated on the copper surface finish can be affected by nickel dissolution in the solder [55,56]. The copper atom in $\mathrm{Cu}_{6} \mathrm{Sn}_{5}$ can be replaced with a nickel atom to form $(\mathrm{Cu}, \mathrm{Ni})_{6} \mathrm{Sn}_{5}$. $(\mathrm{Cu}, \mathrm{Ni})_{6} \mathrm{Sn}_{5}$ has been revealed to be more stable than $\mathrm{Cu}_{6} \mathrm{Sn}_{5}$ at room temperature where the content of $\mathrm{Ni}$ is $\sim 9$ at. \% [57,58]. Before electroplating $\mathrm{Sn}$, a $\mathrm{Ni}$ thin layer may be electroplated to provide a diffusion barrier between $\mathrm{Cu}$ and $\mathrm{Sn}$, lowering the growth rate $[55,59]$. This is because the reaction between $\mathrm{Ni}$ and $\mathrm{Sn}$ is substantially slower at room temperature than the reaction between $\mathrm{Cu}$ and $\mathrm{Sn}$. The response of IMCs with various surface finishes and solder alloys is discussed in this review.

Yoon et al. [60] examined the influence of $\mathrm{Cu} / \mathrm{Ni}$ content on the interfacial interactions between $\mathrm{Sn}-\mathrm{Ag}-\mathrm{xCu}$ solders and $\mathrm{Cu} / \mathrm{ENIG}$ substrate. The creation and development of interfacial IMCs between a Ni-containing Sn-Ag-Ni solder and an ENIG substrate have been investigated. The outcomes contrasted with those of the $\mathrm{Sn}-\mathrm{Ag}-\mathrm{Cu} / \mathrm{ENIG}$ system. The thickness of the $\mathrm{Cu}_{3} \mathrm{Sn}$ IMC was dramatically lowered when more $\mathrm{Cu}$ was introduced to the $\mathrm{Sn}-\mathrm{Ag}$ solder, whereas the overall $\mathrm{Cu}-\mathrm{Sn}$ thickness and $\mathrm{Cu}_{6} \mathrm{Sn}_{5} \mathrm{IMCs}$ increased. At the 
Sn-3.0Ag-0.5Cu/ENIG and Sn-3.0Ag-0.5Ni/ENIG interfaces, $(\mathrm{Ni}, \mathrm{Cu})_{3} \mathrm{Sn}_{4}$ and $\mathrm{Ni}_{3} \mathrm{Sn}_{4}$ IMCs produced. The IMC layer for the $\mathrm{Cu}$ substrate grew 3.3 times quicker compared to the ENIG substrate in the Sn-3.0Ag-0.5Cu/Cu and Sn-3.0Ag-0.5Cu/ENIG joints, respectively. When soldered with $\mathrm{Sn} 3.8 \mathrm{Ag} 0.7 \mathrm{Cu}$, Zheng et al. [61] discovered that immersion tin coating produced a smooth and homogeneous IMC layer when contrasted to copper plated with hot air solder levelling (HASL), OSP, or immersion silver.

Moreover, Ourdjini et al. [62] investigated the IMCs formed during the soldering of lead-free $\mathrm{Sn}-\mathrm{Ag}-\mathrm{Cu}$ solder on copper $(\mathrm{Cu})$, electroless nickel/ immersion gold (ENIG), immersion silver (ImAg), as well as electroless nickel/ electroless palladium/ immersion gold (ENEPIG) surfaces. When ENIG and ENEPIG soldering is completed, numerous morphologies of intermetallic having varied grain sizes occur at the solder joint interface, but when soldering on copper and immersion silver, a single intermetallic morphology form. The surface metallurgy utilized determines the type of intermetallic produced. It is generally known that when soldering on bare $\mathrm{Cu}$ and $\mathrm{ImAg}, \mathrm{Cu}_{6} \mathrm{Sn}_{5} \mathrm{IMC}$ is created during reflow. However, when soldering on ENIG and ENEPIG, $\left(\mathrm{Cu}, \mathrm{Ni}_{6}\right)_{6} \mathrm{Sn}_{5}$ is produced. When comparing the grain sizes of the scallops, it is evident that thinner IMC is generated on $\mathrm{Im}-\mathrm{Ag}$ than when soldering on $\mathrm{Cu}$. In addition, Ha et al. [63] utilized Sn-Ag-Cu solder alloys to investigate the impact of various printed circuit boards (PCBs) between ENIG and ENEPIG. Hence, the IMC thickness in the ENEPIG board was less than that of the ENIG board. Furthermore, when the thermal aging period was increased, the IMC produced on the ENEPIG board developed slower than the ENIG board.

The influence of Pd thickness on the interfacial response in solder joints between SAC and ENEPIG surface finish was investigated by Kim et al. [64]. In samples with 0.05 $\mu \mathrm{m}$ Pd thicknesses or lower, only $(\mathrm{Cu}, \mathrm{Ni})_{6} \mathrm{Sn}_{5}$ was found at the solder interfaces. Once the Pd thickness was raised to $0.1 \mu \mathrm{m}$ or larger, the $(\mathrm{Pd}, \mathrm{Ni}) \mathrm{Sn}_{4}$ phase developed on $(\mathrm{Cu}$, $\mathrm{Ni})_{6} \mathrm{Sn}_{5}$. Moreover, Yoon et al. [65] examined the shear strength and interfacial reaction of eutectic Sn-0.7 wt.\% Cu solder on Cu substrate and electroless Ni-P substrate. At the interface of the $\mathrm{Sn}-0.7 \mathrm{Cu} / \mathrm{Cu}$ substrate, a $\mathrm{Cu}_{6} \mathrm{Sn}_{5} \mathrm{IMC}$ was produced. The IMC produced at the interface of the electroless Ni-P substrate was $\left(\mathrm{Cu}, \mathrm{Ni}_{6}\right)_{6} \mathrm{Sn}_{5}$. As a by-product of the $\mathrm{Cu}-\mathrm{Ni}-\mathrm{Sn}$ reaction, a P-rich $\mathrm{Ni}\left(\mathrm{Ni}_{3} \mathrm{P}\right)$ layer was discovered between the $(\mathrm{Cu}, \mathrm{Ni})_{6} \mathrm{Sn}_{5} \mathrm{IMC}$ layer and the electroless Ni-P layer. Also, the $\mathrm{Ni}_{3} \mathrm{P},\left(\mathrm{Cu}, \mathrm{Ni}_{6} \mathrm{Sn}_{5}\right.$, as well as $\mathrm{Cu}_{6} \mathrm{Sn}_{5}$, layer thicknesses were observed to rise with reflow time. Accordingly, the $\mathrm{Cu}_{6} \mathrm{Sn}_{5},\left(\mathrm{Cu}, \mathrm{Ni}_{6} \mathrm{Sn}_{5}\right.$, and $\mathrm{Ni}_{3} \mathrm{P}$ layers were $1,2.8$, and $3.8 \mu \mathrm{m}$ thick after reflowing at $255^{\circ} \mathrm{C}$ for $10 \mathrm{~min}$. The $(\mathrm{Cu}$, $\mathrm{Ni})_{6} \mathrm{Sn}_{5} \mathrm{IMC}$ layer grew quicker on the $\mathrm{Cu}$ substrate compared to the $(\mathrm{Cu}, \mathrm{Ni})_{6} \mathrm{Sn}_{5} \mathrm{IMC}$ layer that grew on the electroless $\mathrm{Ni}-\mathrm{P}$ substrate. With rising reaction time, the $\mathrm{Ni}$ content of the $\left(\mathrm{Cu}, \mathrm{Ni}_{6} \mathrm{Sn}_{5} \mathrm{IMC}\right.$ layer grew. The interfacial reaction of $\mathrm{Sn}-0.7 \mathrm{Cu}$ on $\mathrm{Cu}, \mathrm{Cu} / \mathrm{Ni} / \mathrm{Ag}$, $\mathrm{Cu} / \mathrm{Ni} / \mathrm{Au}$, as well as $\mathrm{Cu} / \mathrm{Ni}$ substrates are discussed by Yin et al. [66]. In the Sn-0.7Cu solder/Cu solder joint, the IMC layer was thicker compared to the $\mathrm{Sn}-0.7 \mathrm{Cu}$ solder $\mathrm{Cu} / \mathrm{Ni}$ solder joint (Table 1). This is attributable to the fact that molten $\mathrm{Sn}-0.7 \mathrm{Cu}$ solder alloy on $\mathrm{Ni}$ substrate forms IMCs at a slower pace than it occurs on $\mathrm{Cu}$ substrate. Furthermore, given the quick chemical reactions of Ag-Sn and Au-Sn systems, the IMC layers average thickness at the $\mathrm{Sn}-0.7 \mathrm{Cu}$ solder $/ \mathrm{Cu} / \mathrm{Ni}$ interface is thicker compared to $\mathrm{Sn}-0.7 \mathrm{Cu}$ solder $/ \mathrm{Cu} / \mathrm{Ni} / \mathrm{Au}$ as well as $\mathrm{Sn}-0.7 \mathrm{Cu}$ solder $/ \mathrm{Cu} / \mathrm{Ni} / \mathrm{Ag}$ interfaces. This indicates that $\mathrm{Sn}-0.7 \mathrm{Cu}$ solder has higher wettability on $\mathrm{Cu} / \mathrm{Ni} / \mathrm{Ag}$ and $\mathrm{Cu} / \mathrm{Ni} / \mathrm{Au}$ substrates than $\mathrm{Cu} / \mathrm{Ni}$ solder.

Then, Aisha et al. [67] investigated the interfacial response between lead-free Sn-Ag$\mathrm{Cu}-\mathrm{Ni}$ solders and $\mathrm{Cu}, \mathrm{Im}-\mathrm{Ag}$, and ENIG surface finishes during soldering. When soldering on ENIG surface finish, numerous morphologies of intermetallic with varied grain sizes occur at the solder joint interface. However, when soldering on copper and immersion silver, only one intermetallic morphology forms. Besides that, ENIG outperforms ImAg and $\mathrm{Cu}$ in regard to the impact of $\mathrm{Ni}$ addition on surface finish since ENIG's IMCs are thinner than ImAg and $\mathrm{Cu}^{\prime}$ s, implying that ENIG's surface finish can decelerate $\mathrm{Cu}$ diffusion into Sn. Next, Yoon et al. [68] studied the interfacial response and joint reliability of $\mathrm{Sn}-3.0 \mathrm{Ag}-0.5 \mathrm{Cu}$ solder with ENIG and ENEPIG surface finishes. Compared to $\mathrm{Sn}-\mathrm{Ag}$ $\mathrm{Cu} / \mathrm{ENIG}$, the $\mathrm{Sn}-\mathrm{Ag}-\mathrm{Cu} / \mathrm{ENEPIG}$ interface demonstrated greater strength and a smaller 
IMC thickness. In addition, the existence of the ENEPIG substrate's thin Pd layer inhibited the development of the interfacial IMC layer and the $\mathrm{Ni}(\mathrm{P})$ layer consumption, culminating in improved solder joint interfacial stability.

Moreover, Sun et al. [69] looked at the interfacial response of Sn- $0.4 \mathrm{Co}-0.7 \mathrm{Cu}$, Sn$\mathrm{Ag}-\mathrm{Cu}$, and $\mathrm{Sn}-\mathrm{Cu}$ solder alloys on an immersion $\mathrm{Au} /$ electroless $\mathrm{Ni}(\mathrm{P}) / \mathrm{Cu}$ substrate. The analytical findings revealed that a tiny quantity of Co in the solder system would mostly react with $\mathrm{Sn}$ in the solder matrix to create $\mathrm{CoSn}_{2}$. In the $\mathrm{Sn}-\mathrm{Co}-\mathrm{Cu}$ solder, the $\mathrm{Cu}_{6} \mathrm{Sn}_{5}$ particles were the second IMC extensively dispersed. The finer $\mathrm{Cu}_{6} \mathrm{Sn}_{5}$ phase was more equally disseminated in the solder matrix than the rougher $\mathrm{CoSn}_{2}$ particles. For the $\mathrm{Sn}-\mathrm{Cu}, \mathrm{Sn}-\mathrm{Ag}-\mathrm{Cu}$, and $\mathrm{Sn}-\mathrm{Co}-\mathrm{Cu}$ solders, the interfacial IMCs were 4.1, 4.3 and $3.5 \mu \mathrm{m}$ thick, accordingly. In summary, the type of surface finish could affect the growth of IMC. Moreover, the higher reflow peak temperature and longer dwell time could increase the growth behaviour of IMC. Shen et al. [55] investigate the influence of isothermal aging and thermal cycling associated with $\mathrm{Sn}-1.0 \mathrm{Ag}-0.5 \mathrm{Cu}$ (SAC105) and $\mathrm{Sn}-3.0 \mathrm{Ag}-0.5 \mathrm{Cu}$ (SAC305) ball grid on ENIG and ImAg surface finish. They found that ENIG performs better than immersion Ag for applications involving long-term isothermal aging. SAC305 have a higher relative fraction of $\mathrm{Ag}_{3} \mathrm{Sn}$ IMC within the solder and performs better than SAC105 solder alloy. Table 2 displays the investigations on $\mathrm{Sn}-\mathrm{Ag}$-Cu solder alloy on the different surface finish.

Table 2. The Sn-Ag-Cu IMC thickness on the different surface finish.

\begin{tabular}{|c|c|c|c|c|c|c|}
\hline Surface Finish & Solder Alloy & $\begin{array}{c}\text { IMC } \\
\text { Thickness, } \mu \mathrm{m}\end{array}$ & IMC Formation & $\begin{array}{c}\text { Reflow Peak } \\
\text { Temperature, }{ }^{\circ} \mathrm{C}\end{array}$ & $\begin{array}{l}\text { Dwell } \\
\text { Time, Min }\end{array}$ & Ref \\
\hline \multirow{5}{*}{$\mathrm{Cu}-\mathrm{OSP}$} & $\begin{array}{l}\text { Sn-xAg- } 0.5 \mathrm{Cu} \\
(\mathrm{x}=3.0,4.0)\end{array}$ & $4-5$ & $\mathrm{Cu}_{6} \mathrm{Sn}_{5}, \mathrm{Ag}_{3} \mathrm{Sn}, \mathrm{Cu}_{3} \mathrm{Sn}$ & 230 & 20 & [70] \\
\hline & Sn-1.0Ag-0.5Cu & $3-5$ & $\mathrm{Cu}_{6} \mathrm{Sn}_{5}, \mathrm{Ag}_{3} \mathrm{Sn}, \mathrm{Cu}_{3} \mathrm{Sn}$ & 250 & - & [71] \\
\hline & Sn-3.0Ag-0.5Cu & $2.5-3$ & $\mathrm{Cu}_{6} \mathrm{Sn}_{5}, \mathrm{Ag}_{3} \mathrm{Sn}, \mathrm{Cu}_{3} \mathrm{Sn}$ & 300 & - & [72] \\
\hline & Sn-3.8Ag-0.7Cu & $1.0-2.3$ & $\mathrm{Cu}_{6} \mathrm{Sn}_{5}, \mathrm{Ag}_{3} \mathrm{Sn}, \mathrm{Cu}_{3} \mathrm{Sn}$ & 270 & 2 & [51] \\
\hline & Sn-3.8Ag-0.7Cu & 2.0 & $\mathrm{Cu}_{6} \mathrm{Sn}_{5}, \mathrm{Ag}_{3} \mathrm{Sn}, \mathrm{Cu}_{3} \mathrm{Sn}$ & 244 & 1 & [61] \\
\hline \multirow{4}{*}{ ENIG } & Sn-4.0Ag-0.5Cu & $<2.0$ & $\begin{array}{c}\mathrm{Ni}_{3} \mathrm{Sn}_{4}, \mathrm{Ni}_{3} \mathrm{Sn}_{2}, \mathrm{Cu}_{6} \mathrm{Sn}_{5},\left(\mathrm{Cu}, \mathrm{Ni}_{6} \mathrm{Sn}_{5}\right. \\
\mathrm{Ag}_{3} \mathrm{Sn},(\mathrm{Ni}, \mathrm{Cu})_{3} \mathrm{Sn}_{4}, \mathrm{Ag}_{3} \mathrm{Sn}\end{array}$ & 250 & 1 & [62] \\
\hline & Sn-3.5Ag-0.7Cu & $<2.0$ & $\begin{array}{c}\mathrm{Ni}_{3} \mathrm{Sn}_{4}, \mathrm{Ni}_{3} \mathrm{Sn}_{2}, \mathrm{Cu}_{6} \mathrm{Sn}_{5},\left(\mathrm{Cu}, \mathrm{Ni}_{6} \mathrm{Sn}_{5}\right. \\
\mathrm{Ag}_{3} \mathrm{Sn},(\mathrm{Ni}, \mathrm{Cu})_{3} \mathrm{Sn}_{4}, \mathrm{Ag}_{3} \mathrm{Sn}\end{array}$ & 255 & 1 & [73] \\
\hline & Sn-3.0Ag-0.5Cu & $1.5-2$ & $\begin{array}{c}\mathrm{Ni}_{3} \mathrm{Sn}_{4}, \mathrm{Ni}_{3} \mathrm{Sn}_{2}, \mathrm{Cu}_{6} \mathrm{Sn}_{5},\left(\mathrm{Cu}, \mathrm{Ni}_{6} \mathrm{Sn}_{5}\right. \\
\mathrm{Ag}_{3} \mathrm{Sn},(\mathrm{Ni}, \mathrm{Cu})_{3} \mathrm{Sn}_{4}, \mathrm{Ag}_{3} \mathrm{Sn}\end{array}$ & 250 & - & [74] \\
\hline & Sn-3.0Ag- $0.5 \mathrm{Cu}$ & $2-3$ & $\begin{array}{c}\mathrm{Ni}_{3} \mathrm{Sn}_{4}, \mathrm{Ni}_{3} \mathrm{Sn}_{2}, \mathrm{Cu}_{6} \mathrm{Sn}_{5},\left(\mathrm{Cu}, \mathrm{Ni}_{6} \mathrm{Sn}_{5}\right. \\
\mathrm{Ag}_{3} \mathrm{Sn},(\mathrm{Ni}, \mathrm{Cu})_{3} \mathrm{Sn}_{4}, \mathrm{Ag}_{3} \mathrm{Sn}\end{array}$ & 245 & 1 & [75] \\
\hline \multirow{3}{*}{ ENEPIG } & Sn-3.0Ag- $0.5 \mathrm{Cu}$ & 2.3 & $\begin{array}{c}\mathrm{Ni}_{3} \mathrm{Sn}_{4}, \mathrm{Ni}_{3} \mathrm{Sn}_{2}, \mathrm{PdSn}_{4}, \mathrm{AuSn}_{4}, \mathrm{Cu}_{6} \mathrm{Sn}_{5} \\
\left(\mathrm{Cu}, \mathrm{Ni}_{6} \mathrm{Sn}_{5}, \mathrm{Ag}_{3} \mathrm{Sn},(\mathrm{Ni}, \mathrm{Cu})_{3} \mathrm{Sn}_{4}\right.\end{array}$ & 250 & 1 & [76] \\
\hline & Sn-3.0Ag- $0.5 \mathrm{Cu}$ & $1.3-2.5$ & $\begin{array}{c}\mathrm{Ni}_{3} \mathrm{Sn}_{4}, \mathrm{Ni}_{3} \mathrm{Sn}_{2}, \mathrm{PdSn}_{4}, \mathrm{AuSn}_{4}, \mathrm{Cu}_{6} \mathrm{Sn}_{5} \\
(\mathrm{Cu}, \mathrm{Ni})_{6} \mathrm{Sn}_{5}, \mathrm{Ag}_{3} \mathrm{Sn},(\mathrm{Ni}, \mathrm{Cu})_{3} \mathrm{Sn}_{4}\end{array}$ & 260 & 1 & [63] \\
\hline & Sn-4.0Ag-0.5Cu & $1.0-2.5$ & $\begin{array}{c}\mathrm{Ni}_{3} \mathrm{Sn}_{4}, \mathrm{Ni}_{3} \mathrm{Sn}_{2}, \mathrm{PdSn}_{4}, \mathrm{AuSn}_{4}, \mathrm{Cu}_{6} \mathrm{Sn}_{5} \\
\left(\mathrm{Cu}, \mathrm{Ni}_{6} \mathrm{Sn}_{5}, \mathrm{Ag}_{3} \mathrm{Sn},(\mathrm{Ni}, \mathrm{Cu})_{3} \mathrm{Sn}_{4}\right.\end{array}$ & 230 & - & [77] \\
\hline \multirow[b]{2}{*}{ Im-Ag } & Sn-3.0Ag-0.5Cu & $2-3$ & $\mathrm{Cu}_{6} \mathrm{Sn}_{5}, \mathrm{Cu}_{3} \mathrm{Sn}, \mathrm{Ag}_{3} \mathrm{Sn}$ & 250 & 1 & [78] \\
\hline & $\begin{array}{c}\text { Sn-3.8Ag-0.7Cu- } \\
0.15 \mathrm{Ni}- \\
1.4 \mathrm{Sb}-3.0 \mathrm{Bi}, \\
\mathrm{Sn}-3.4 \mathrm{Ag}- \\
0.5 \mathrm{Cu}-3.3 \mathrm{Bi} \text {, and } \\
\mathrm{Sn}-3.8 \mathrm{Ag}- \\
0.8 \mathrm{Cu}-3.0 \mathrm{Bi} .\end{array}$ & $10-12$ & $\mathrm{Cu}_{6} \mathrm{Sn}_{5}, \mathrm{Cu}_{3} \mathrm{Sn}, \mathrm{Ag}_{3} \mathrm{Sn}$ & 250 & 1 & [79] \\
\hline
\end{tabular}

\section{Effect of Aging Time and Temperature}

Recognizing the interfacial intermetallic reaction kinetics between the solder and the substrate in the electronic assembly context will help us extend the service life of the 
solder joints. Studying the impacts of aging time and temperature on the characteristics of interfacial intermetallics is thus critical. $\mathrm{Cu}_{6} \mathrm{Sn}_{5}$ and $\mathrm{Cu}_{3} \mathrm{Sn}$ phases are frequent interfacial layers between the $\mathrm{Cu}$ substrate and the solder during the soldering of an $\mathrm{Sn}-\mathrm{Cu}$ solder system. Interfacial IMC layers are formed by two primary reactions: (i) dissolving the metal substrate in molten metal as well as (ii) connecting the active component elements in the solder material with the substrate material [80]. The formation of $\mathrm{Cu}_{6} \mathrm{Sn}_{5}$ occurs the reaction of molten solder and the substrate [81]:

$$
5 \mathrm{Sn}+6 \mathrm{Cu} \rightarrow \mathrm{Cu}_{6} \mathrm{Sn}_{5}
$$

Meanwhile, $\mathrm{Cu}_{3} \mathrm{Sn}$ IMC can be formed either through the decomposition of $\mathrm{Cu}_{6} \mathrm{Sn}_{5}$ as in reaction 2 and 3 or through the consumption of $\mathrm{Cu}$ (reaction 4 ) during solid-state diffusion process [81]:

$$
\begin{gathered}
\mathrm{Cu}_{6} \mathrm{Sn}_{5}+9 \mathrm{Cu} \rightarrow 5 \mathrm{Cu}_{3} \mathrm{Sn} \\
\mathrm{Cu}_{6} \mathrm{Sn}_{5}+3 \mathrm{Sn} \rightarrow 2 \mathrm{Cu}_{3} \mathrm{Sn} \\
3 \mathrm{Cu}+\mathrm{Sn} \rightarrow \mathrm{Cu}_{3} \mathrm{Sn}
\end{gathered}
$$

Understanding the solder-substrate interface bonding response is significant to decide the reliability of solder interconnections. Investigators researched the development behavior of interfacial IMCs during solid-state annealing to improve solder coating reliability. The intermetallic phase is controlled directly by the solid-state diffusion process. The IMC layer will develop in the solid-state, causing solder joint reliability to deteriorate with time. The IMC layers grow gradually, which decreases defects and ductility such as voids at the interface, which could translate into failure for the solder interconnects. Under the aforementioned thermal conditions, the present IMC in solid joints will remain to expand through solid-state diffusion. An empirical power-law may be utilized to explain the isothermal growth kinetics of a continuous IMCs layer overall:

$$
\mathrm{d}-\mathrm{d}_{\mathrm{o}}=D \mathrm{t}^{\mathrm{n}}
$$

in which $\mathrm{n}$ denotes the time exponent, $\mathrm{t}$ denotes the reaction time, $\mathrm{D}$ denotes the growth rate coefficient, $d$ denotes the aged thickness after time $t$, and $d_{o}$ denote the as-soldered thickness of the reaction layer. It has been proven that a diffusion mechanism is primarily accountable for the IMC layer formation of many solder joints with time exponents of $\sim 0.5$ [82]:

$$
\mathrm{D}=\mathrm{Do} \exp \left(\frac{-\mathrm{Q}}{\mathrm{RT}}\right),
$$

in which $\mathrm{T}$ denotes the aging temperature, $\mathrm{R}$ denotes the gas constant, $\mathrm{Q}$ denotes the activation energy, and $\mathrm{D}_{\mathrm{o}}$ denotes the growth rate constant in the absolute unit. Moreover, the activation energy may be estimated from the plot's slope between $1 / \mathrm{T}$ and $\mathrm{ln}$ $\mathrm{K}$ employing the linear regression model. The IMC layer produced utilizing Sn-based solder on the $\mathrm{Cu}$ substrate represents typical $\mathrm{Cu}_{6} \mathrm{Sn}_{5}$. Various IMC can occur in addition to $\mathrm{Cu}_{6} \mathrm{Sn}_{5}$, relying on the solder compositions as well as surface finishes on the substrate. $\mathrm{Cu}_{3} \mathrm{Sn}$ intermetallic can be generated during high-temperature aging when the solder is deposited on the $\mathrm{Cu}$ [83], in addition to the $\mathrm{Cu}_{6} \mathrm{Sn}_{5} . \mathrm{Cu}_{3} \mathrm{Sn}$ usually observed at the ageing temperature above $150{ }^{\circ} \mathrm{C}$ [81]. The activation energy of $\mathrm{Cu}_{6} \mathrm{Sn}_{5}$ is lower than that of $\mathrm{Cu}_{3} \mathrm{Sn}$, which implies that $\mathrm{Cu}_{6} \mathrm{Sn}_{5}$ will develop quicker than $\mathrm{Cu}_{3} \mathrm{Sn}$, as per the Arrhenius relationship. As a result, inhibiting the development of $\mathrm{Cu}_{6} \mathrm{Sn}_{5}$ will be more successful than limiting the development of $\mathrm{Cu}_{3} \mathrm{Sn}$ [80]. Following the soldering step, the IMCs layer remains to expand, and the greater the temperature, the quicker the IMC layer grows. The IMC generated in $\mathrm{Sn}-3 \mathrm{Ag}-0.5 \mathrm{Cu}$, and $\mathrm{Sn}-3 \mathrm{Ag}-0.5-\mathrm{Cu}-0.06 \mathrm{Ni}-0.01 \mathrm{Ge}$ solder BGA packages having Ag/Cu pad is discussed by Chuang et al. [84]. They discovered that after aging at $150{ }^{\circ} \mathrm{C}$, an extra $\mathrm{Cu}_{3} \mathrm{Sn}$ IMCs layer forms at the interface between the $\mathrm{Cu}_{6} \mathrm{Sn}_{5}$ and $\mathrm{Cu}$ pad in the $\mathrm{Sn}-3 \mathrm{Ag}-0.5 \mathrm{Cu}$ specimen. In the $\mathrm{Sn}-3 \mathrm{Ag}-0.5 \mathrm{Cu}-0.06 \mathrm{Ni}-0.01 \mathrm{Ge}$ specimen, though, the similar sort of intermetallic development is blocked. The isothermal aging of 
the Sn-0.7Cu solder/Ni BGA joint has been studied by Yoon et al. [85]. The interaction between the $\mathrm{Ni}$ layer and molten solder established a $(\mathrm{Cu}, \mathrm{Ni})_{6} \mathrm{Sn}_{5}$ layer at the interface during soldering. Only $(\mathrm{Cu}, \mathrm{Ni})_{6} \mathrm{Sn}_{5}$ was found since the sample was aged at $70-150{ }^{\circ} \mathrm{C}$. The solder/Ni interface revealed a duplex structure of $(\mathrm{Cu}, \mathrm{Ni})_{6} \mathrm{Sn}_{5}$ as well as $(\mathrm{Ni}, \mathrm{Cu})_{3} \mathrm{Sn}_{4}$ after 50 days of isothermal aging at $170{ }^{\circ} \mathrm{C}$, as depicted in Figure 4 . Cu diffusion into the interface is reduced, resulting in the creation of the $(\mathrm{Ni}, \mathrm{Cu})_{3} \mathrm{Sn}_{4} \mathrm{IMC}$.
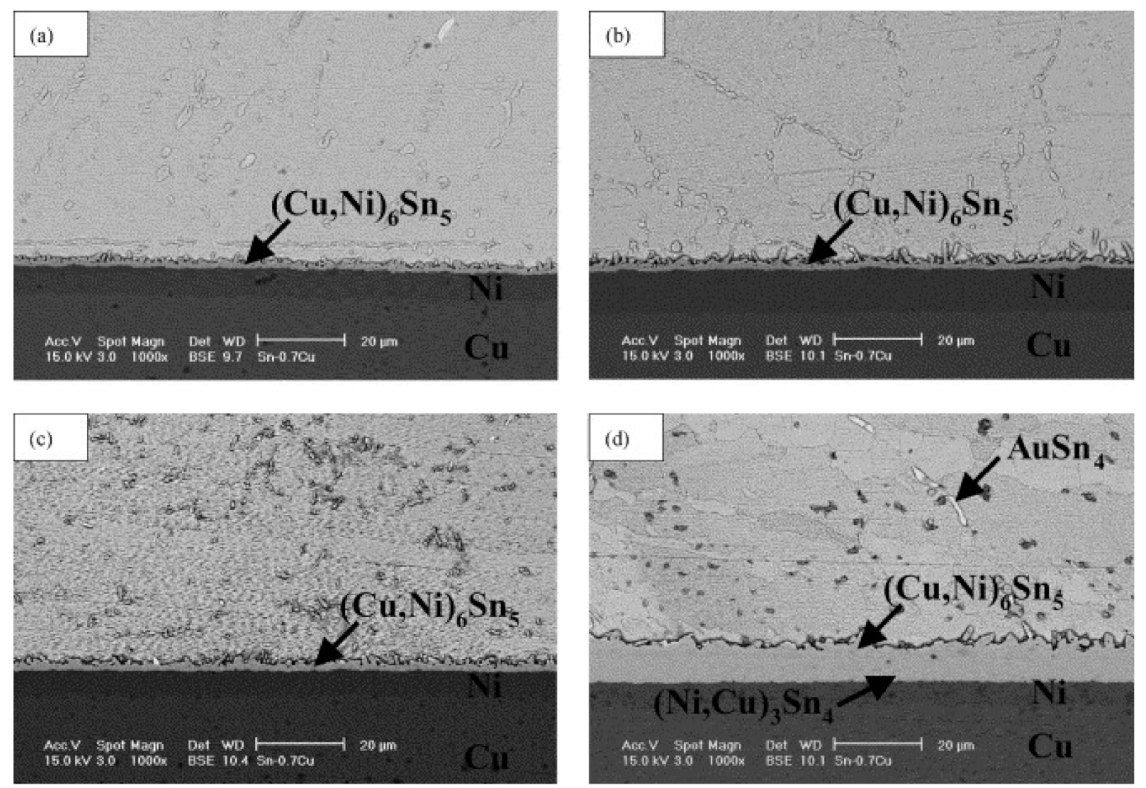

Figure 4. The Sn0.7Cu solder/Ni BGA SEM micrographs; Joints after aging for 100 days at a variety of temperatures: (a) $70{ }^{\circ} \mathrm{C}$, (b) $100{ }^{\circ} \mathrm{C}$, (c) $150{ }^{\circ} \mathrm{C}$, and (d) $170{ }^{\circ} \mathrm{C}$ [85].

$\mathrm{Bi}, \mathrm{Ju}$ and Lin [3] examined the impact of introducing elemental Bi and Er to a low $\mathrm{Ag}$ solder alloy $\mathrm{Sn}-\mathrm{x}(1.0,1.5,2.0) \mathrm{Ag}-0.3 \mathrm{Cu}-3.0 \mathrm{Bi}-0.05 \mathrm{Er}$ on the development of the interfacial IMC layer (wt.\%). The IMC layer thickness at the interface of a $\mathrm{Cu} / \mathrm{SACBE} / \mathrm{Cu}$ joint was discovered to be much less than that of a $\mathrm{Cu} / \mathrm{SAC} / \mathrm{Cu}$ joint. Also, the inclusion of $\mathrm{Bi}$ and $\mathrm{Er}$ successfully prevented the interfacial IMC layer from overgrowing during thermal aging. Furthermore, Hodulova et al. [86] studied the influence of $\mathrm{Bi}$ and In inclusions on the development of intermetallic phases in lead-free $\mathrm{Sn}-3.7 \mathrm{Ag}-0.7 \mathrm{Cu}$ solder joints. The joints were then matured in a convection oven at temperatures varying from 130 to $170{ }^{\circ} \mathrm{C}$ for 2 to 16 days. During soldering, $\mathrm{Cu}_{6} \mathrm{Sn}_{5}$ is created, while $\mathrm{Cu}_{3} \mathrm{Sn}$ is formed during solid state aging. Besides, in the lead-free solder, the growth rate of $\mathrm{Cu}_{3} \mathrm{Sn}$ was slowed by $\mathrm{Bi}$ and In inclusions. $\mathrm{Cu}_{3}(\mathrm{Sn}, \mathrm{In})$ or $\mathrm{Cu}_{3}(\mathrm{Sn}, \mathrm{Bi})$ compounds can occur at $\mathrm{Cu}_{3} \mathrm{Sn}$ grain boundaries, in which they restrict Sn diffusion, seeing as Bi and In can replace Sn in IMCs. At greater concentrations, indium is thought to promote copper diffusion in $\mathrm{Cu}_{6}(\mathrm{Sn}, \mathrm{In})_{5}$ and contribute to the creation of In-based compounds. In addition, Lejuste et al. [87] investigated the introduction of In to Sn-3.0Ag-0.4Cu-7.0In composite solder with $\mathrm{Cu}$ substrate. Two IMC layers, $\mathrm{Cu}_{6}(\mathrm{Sn}, \mathrm{In})_{5}$ as well as $\mathrm{Cu}_{3}(\mathrm{Sn}, \mathrm{In})$, were produced at the interface, according to the findings. They discovered that $\mathrm{Cu}_{3}(\mathrm{Sn}, \mathrm{In})$ has a reduced growth coefficient than $\mathrm{Cu}_{6}(\mathrm{Sn}, \mathrm{In})_{5}$, implying that the inclusion of the In element can delay the formation of the IMC layer during thermal aging.

Additionally, Wu et al. [88] examined the IMC growth kinetics impact between Sn-3Ag3Bi-10In and $\mathrm{Cu}$ substrate at temperatures of 120,150 , and $180{ }^{\circ} \mathrm{C}$, as well as aging times of up until 40 days. This results in $\mathrm{Cu}_{6}(\mathrm{Sn}, \mathrm{In})_{5}$ and $\mathrm{Cu}_{3}(\mathrm{Sn}, \mathrm{In})$ appearing as IMC layers at the interface, and they discovered that the IMC thickness of reactive layers did not vary greatly with aging time at $120^{\circ} \mathrm{C}$ and $150{ }^{\circ} \mathrm{C}$. However, it abided by a diffusion-controlled mechanism at $180^{\circ} \mathrm{C}$. Also, Kanlayasiri and Sukpimai [89] studied the influence of indium 
on the development of the interfacial layer on SAC0307. Indium had no influence on the IMCs layer thickness, according to the findings.

Furthermore, the inclusion of indium in the solder inhibited the formation of the $\mathrm{Cu}_{3} \mathrm{Sn}$ layer by lowering the $\mathrm{Cu}_{6} \mathrm{Sn}_{5}$ to $\mathrm{Cu}_{3} \mathrm{Sn}$ conversion. The activation energy of $\mathrm{Cu}_{3} \mathrm{Sn}$ rose as the indium level rose. Moreover, Wang et al. [90] also studied the introduction of $\mathrm{Zn}$ to the $\mathrm{Sn}-0.7 \mathrm{Cu}$ solder alloy. Small quantities of $\mathrm{Zn}$ added to the solder have been shown to inhibit the development of the IMC interface during thermal aging. These findings indicate that adding $\mathrm{Zn}$ to the $\mathrm{Sn}-0.7 \mathrm{Cu}$ alloy enhances the mechanical characteristics and reliability of the solder joints. In addition, Zeng, Xue, Zhang, Gao, Dai and Luo [38] explored the insertion of $\mathrm{Zn}$ atoms into IMCs as a means of inhibiting IMC particle development during thermal aging. Thus, $(\mathrm{Cu}, \mathrm{Ni})_{6} \mathrm{Sn}_{5} \mathrm{IMCs}$ became $(\mathrm{Cu}, \mathrm{Ni}, \mathrm{Zn})_{6} \mathrm{Sn}_{5} \mathrm{IMCs}$ after $\mathrm{Zn}$ was added to Sn-0.7Cu solder. During thermal aging at $150{ }^{\circ} \mathrm{C}$, they discovered that the $(\mathrm{Cu}$, $\mathrm{Ni}, \mathrm{Zn})_{6} \mathrm{Sn}_{5}$ IMCs are more stable than the $\left(\mathrm{Cu}, \mathrm{Ni}_{6} \mathrm{Sn}_{5}\right.$ and $\mathrm{Cu}_{6} \mathrm{Sn}_{5} \mathrm{IMCs}$.

Alternatively, Wang et al. [91] studied the impact of moderate Ni, Co, and Fe additions on the reaction between the $\mathrm{Sn}-\mathrm{Ag}-\mathrm{Cu}$ solder and the $\mathrm{Cu}$ substrate. Also, the researchers discovered that both $\mathrm{Cu}_{6} \mathrm{Sn}_{5}$ and $\mathrm{Cu}_{3} \mathrm{Sn}$ phases developed during solid-state aging. The inclusion of $\mathrm{Ni}, \mathrm{Co}$, and $\mathrm{Fe}$, on the other hand, resulted in a substantially thinner $\mathrm{Cu}_{3} \mathrm{Sn}$ layer. In addition, Rizvi, Chan, Bailey, Lu and Islam [52] investigated IMC production of Sn-2.8Ag-0.5Cu during isothermal aging with the inclusion of $1 \mathrm{wt} . \% \mathrm{Bi}$. It was discovered that adding $1 \mathrm{wt} . \%$ Bi to the $\mathrm{Sn}-2.8 \mathrm{Ag}-0.5 \mathrm{Cu}$ solder prevents the development of unwanted IMCs. Hence, the IMC between the Sn-2.8Ag-0.5Cu solder and the Cu substrate similarly changes morphology from scallop to planar.

On the other hand, Dong et al. [92] investigated the impacts of tiny amounts of RE elements on Sn-58Bi and Sn-58Bi-Ag. In conclusion, the IMC thicknesses of the solder joint were raised during high-temperature aging. Table 3 outlines the link between the thickness of the IMC layer and the aging time of the solder alloy.

Table 3. Effect of alloying element and aging time on solder alloys interfacial IMCs.

\begin{tabular}{|c|c|c|c|c|c|c|}
\hline Solder & Element & $\begin{array}{c}\text { Aging } \\
\text { Temperature, }{ }^{\circ} \mathrm{C}\end{array}$ & Aging Time, $h$ & $\begin{array}{l}\text { Rate Constant of } \\
\text { IMC Growth } \\
\text { ( } \mu \mathrm{m} / \text { Day })\end{array}$ & IMC Formation & Ref \\
\hline Sn-3.0Ag-0.4Cu & In & $100-180$ & 1506 & 0.13 & $\mathrm{Cu}_{6} \mathrm{Sn}_{5}, \mathrm{Ag}_{3} \mathrm{Sn}, \mathrm{Cu}_{3} \mathrm{Sn}$ & [87] \\
\hline Sn-3Ag-3Bi & In & 120,150 and 180 & 960 & 0.2 & $\mathrm{Cu}_{6} \mathrm{Sn}_{5}, \mathrm{Ag}_{3} \mathrm{Sn}, \mathrm{Cu}_{3} \mathrm{Sn}$ & [88] \\
\hline Sn-2.8Ag-0.5Cu & $\mathrm{Bi}$ & 150 & 336 & 0.5 & $\mathrm{Cu}_{6} \mathrm{Sn}_{5}, \mathrm{Ag}_{3} \mathrm{Sn}, \mathrm{Cu}_{3} \mathrm{Sn}$ & [52] \\
\hline Sn-58Bi & $\mathrm{Ce}, \mathrm{La}$ & 80 & 168 & $0.5-0.79$ & $\mathrm{Cu}_{6} \mathrm{Sn}_{5}, \mathrm{Cu}_{3} \mathrm{Sn}$ & [92] \\
\hline Sn-58Bi & $\mathrm{Cr}$ & 100 & 240 & 0.19 & $\mathrm{Cu}_{6} \mathrm{Sn}_{5}, \mathrm{Cu}_{3} \mathrm{Sn}$ & [93] \\
\hline Sn-Bi & $\mathrm{Ag}$ & 100 & 600 & 0.1 & $\mathrm{Cu}_{6} \mathrm{Sn}_{5}, \mathrm{Cu}_{3} \mathrm{Sn}, \mathrm{Ag}_{3} \mathrm{Sn}$ & [94] \\
\hline Sn-2.5Ag-0.8Cu & $\mathrm{Fe}, \mathrm{Co}$ and $\mathrm{Ni}$ & 160 & 2000 & 0.44 & $\mathrm{Cu}_{6} \mathrm{Sn}_{5}, \mathrm{Ag}_{3} \mathrm{Sn}, \mathrm{Cu}_{3} \mathrm{Sn}$ & [91] \\
\hline Sn-3.0Ag-0.5Cu & $\mathrm{TiO}_{2}$ & 190 & 720 & 0.37 & $\mathrm{Cu}_{6} \mathrm{Sn}_{5}, \mathrm{Ag}_{3} \mathrm{Sn}, \mathrm{Cu}_{3} \mathrm{Sn}$ & [95] \\
\hline Sn- $0.7 \mathrm{Cu}$ & $\mathrm{Ni}$ & 170 & 2400 & 0.09 & $\mathrm{Cu}_{6} \mathrm{Sn}_{5}, \mathrm{Cu}_{3} \mathrm{Sn},(\mathrm{Ni}, \mathrm{Cu})_{6} \mathrm{Sn}_{5}$ & [85] \\
\hline Sn-3.0Ag-0.5Cu & $\mathrm{Bi}$ and $\mathrm{Er}$ & 150 & 500 & 0.14 & $\mathrm{Cu}_{6} \mathrm{Sn}_{5}, \mathrm{Ag}_{3} \mathrm{Sn}, \mathrm{Cu}_{3} \mathrm{Sn}$ & [3] \\
\hline Sn-3.7Ag-0.7Cu & Bi and In & 150 & 400 & 2.5 & $\begin{array}{c}\mathrm{Cu}_{6} \mathrm{Sn}_{5}, \mathrm{Ag}_{3} \mathrm{Sn}_{,} \mathrm{Cu}_{3} \mathrm{Sn},(\mathrm{Ni}, \\
\mathrm{Cu})_{3} \mathrm{Sn}_{4}\end{array}$ & [86] \\
\hline Sn-3.0Ag-0.5Cu & Mo & 180 & 480 & 0.7 & $\mathrm{Cu}_{6} \mathrm{Sn}_{5}, \mathrm{Ag}_{3} \mathrm{Sn}, \mathrm{Cu}_{3} \mathrm{~S}$ & [96] \\
\hline $\mathrm{Sn}-0.7 \mathrm{Cu}$ & $\mathrm{Zn}$ & 150 & 480 & 0.35 & $\begin{array}{c}\mathrm{Cu}_{6} \mathrm{Sn}_{5}, \mathrm{Ag}_{3} \mathrm{Sn}_{2} \mathrm{Cu}_{3} \mathrm{Sn}, \mathrm{CuZn}, \\
\mathrm{Cu}_{5} \mathrm{Zn}_{8}\end{array}$ & [90] \\
\hline Sn-0.7Cu-0.06Zn & $\mathrm{Ni}$ & 150 & 500 & 0.25 & $\begin{array}{c}\mathrm{Cu}_{6} \mathrm{Sn}_{5}, \mathrm{Ag}_{3} \mathrm{Sn}, \mathrm{Cu}_{3} \mathrm{Sn},(\mathrm{Ni} \\
\mathrm{Cu})_{3} \mathrm{Sn}_{4}, \mathrm{CuZn},(\mathrm{Ni}, \mathrm{Cu})_{6} \mathrm{Sn}_{5}\end{array}$ & [97] \\
\hline Sn99.3Cu0.7 & $\mathrm{Ge}$ & 150 & 720 & 0.22 & $\mathrm{Cu}_{6} \mathrm{Sn}_{5}, \mathrm{Cu}_{3} \mathrm{Sn}$ & [98] \\
\hline Sn-0.3Ag-0.7Cu & $\mathrm{Mn}$ & 190 & 1152 & 0.10 & $\mathrm{Cu}_{6} \mathrm{Sn}_{5}, \mathrm{Ag}_{3} \mathrm{Sn}, \mathrm{Cu}_{3} \mathrm{Sn}$ & [99] \\
\hline Sn-1.0Ag-0.5Cu & $\mathrm{Fe}$ and $\mathrm{Bi}$ & 125 & 720 & 0.23 & $\mathrm{Cu}_{6} \mathrm{Sn}_{5}, \mathrm{Ag}_{3} \mathrm{Sn}, \mathrm{Cu}_{3} \mathrm{Sn}, \mathrm{FeSn}_{2}$ & [100] \\
\hline $\mathrm{Sn}-4.0 \mathrm{Ag}-0.5 \mathrm{Cu}$ & $\mathrm{Bi}$ and $\mathrm{Ni}$ & 175 & 2000 & 0.3 & $\begin{array}{c}\mathrm{Cu}_{6} \mathrm{Sn}_{5}, \mathrm{Ag}_{3} \mathrm{Sn}, \mathrm{Cu}_{3} \mathrm{Sn},(\mathrm{Ni} \\
\mathrm{Cu})_{3} \mathrm{Sn}_{4},(\mathrm{Ni}, \mathrm{Cu})_{6} \mathrm{Sn}_{5}\end{array}$ & [81] \\
\hline
\end{tabular}




\section{Effect of Solder Volume}

The effect of solder volume has been investigated by several researchers to comprehend the IMC thickness at the solder joints [101-104]. Different solder volumes give rise to different interfacial reactions which in turns affect the formation of interfacial IMC and the microstructure [101]. Microstructure anisotropy and Joule heating could triggered the failure in microbumps [101]. The volume effect between $\mathrm{Ni}$ and $\mathrm{Sn}-\mathrm{Ag}-\mathrm{Cu}$ has been investigated by Yang et al. [105]. Solder spheres of three different sizes (300, 500, and $760 \mu \mathrm{m}$ in diameter) were employed, with three distinct $\mathrm{Cu}$ concentrations (0.3, 0.5, and $0.7 \mathrm{wt} . \%)$. They investigated how $\mathrm{Cu}$ concentration in solder, solder volume, as well as temperature influenced soldering reactions between $\mathrm{Sn}-\mathrm{Ag}-\mathrm{Cu}$ solder and Ni during bump metallization. The kind of IMC evolves from $(\mathrm{Cu}, \mathrm{Ni})_{6} \mathrm{Sn}_{5}$ to $(\mathrm{Ni}, \mathrm{Cu})_{3} \mathrm{Sn}_{4}$ when the remaining visible $\mathrm{Cu}$ concentration in the solder reduces and the solder volume decreases. They also verify that when the temperature drops, the crucial $\mathrm{Cu}$ concentration diminishes. The $\mathrm{Cu}$ concentration gets increasingly complicated to maintain as the solder volume decreases. Besides, Chang et al. [106] explored how solder volume and $\mathrm{Cu}$ concentration affected $\mathrm{Cu}$ pad consumption during reflow soldering. Only $\mathrm{Cu}_{6} \mathrm{Sn}_{5}$, with the typical scallop-type morphology, were developed at the interface for all experimental circumstances, including $\mathrm{Sn}-3.0 \mathrm{Ag}$ and Sn-3.0Ag-0.7Cu, 400-960 $\mu \mathrm{m}$ solder balls, with 1-5 reflow cycles. By raising the original $\mathrm{Cu}$ concentration, expanding the reflow number cycles, and lowering the solder volume, the scallop sizes grew. As demonstrated in Figure 5, a reduction in solder volume facilitated the production of bigger $\mathrm{Cu}_{6} \mathrm{Sn}_{5}$ scallops. This was due to the fact that the $\mathrm{Cu}$ concentration in the solder grew quicker in smaller solder balls than in bigger ones. According to the $\mathrm{Cu}$ concentration impact, the scallops kept growing as the smaller balls were exposed to greater $\mathrm{Cu}$ concentrations for extended amounts of time. In their investigation on SAC405 solders reacting with EN(B)EPIG surface finish, Azlina et al. [107] obtained comparable findings. They reported that after reflow soldering, the average thickness of the intermetallic for bigger solders is thicker than for smaller solders. In the meantime, since the low concentration of $\mathrm{Cu}$ atoms is accessible in a small solder ball, smaller solder sizes formed thicker intermetallic than bigger solders after reflowing process.
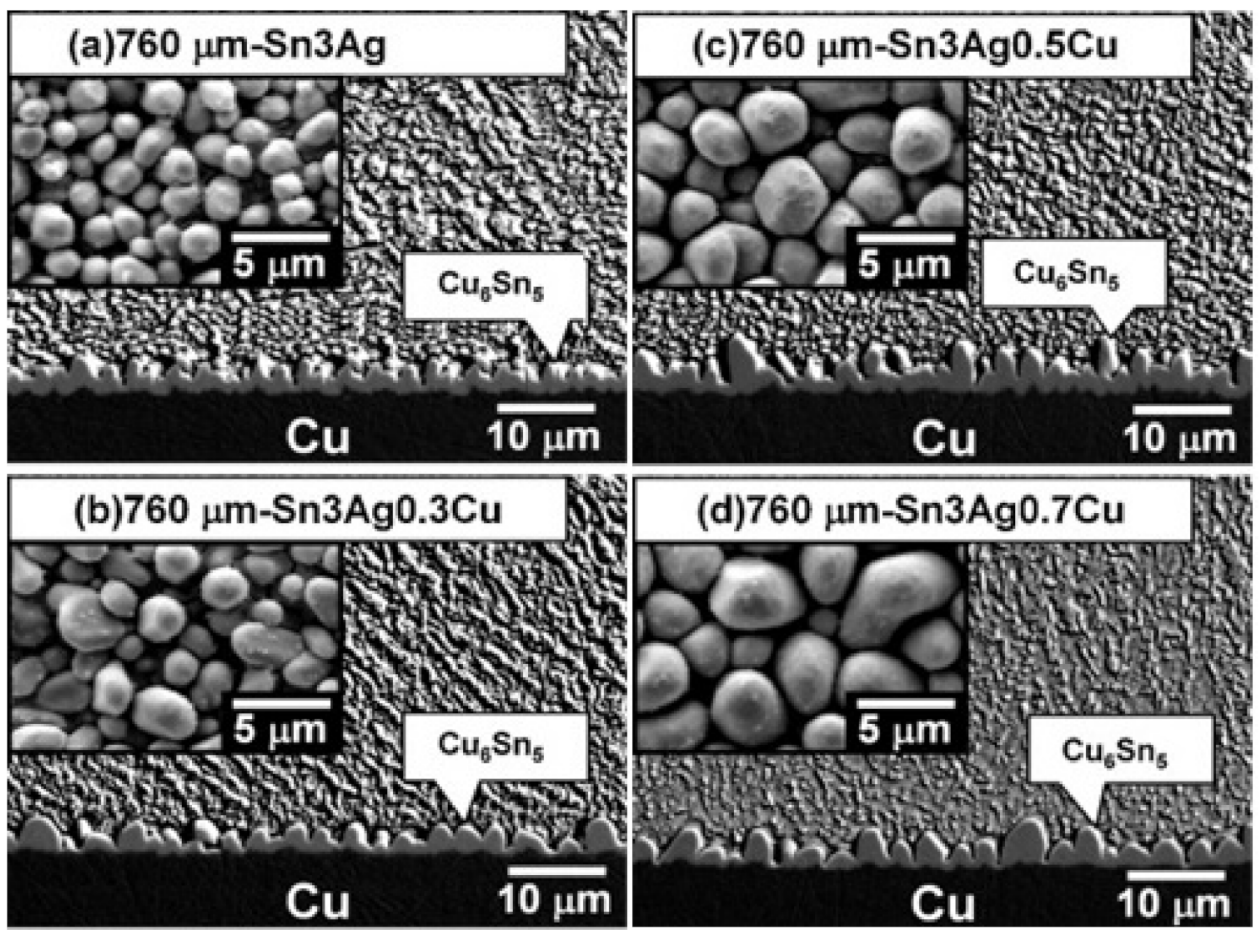

(d) $760 \mu \mathrm{m}-\mathrm{Sn} 3 \mathrm{Ag} 0.7 \mathrm{Cu}$

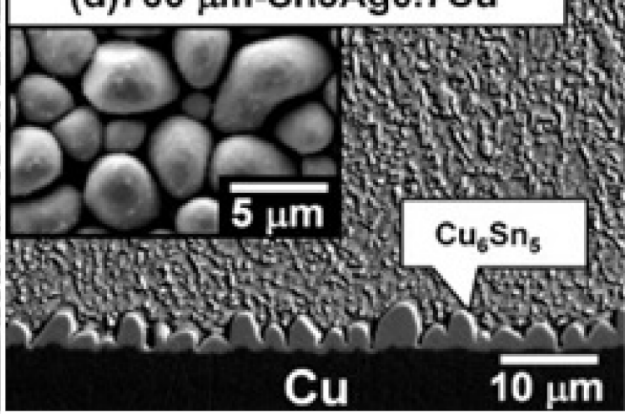

Figure 5. Cross-section and top-view (insets) micrographs showing the microstructure for the Sn3Ag0.5Cu solder with different ball sizes.(a) 960, (b) 760, (c) 500, and (d) $400 \mu \mathrm{m}$ [106]. 
Furthermore, Liu et al. [108] studied the effect on the interfacial reaction between $\mathrm{Cu}$ pads and Sn-3.0Ag-0.5Cu solder balls. Solder balls with diameters of 200, 300, 400, and $500 \mu \mathrm{m}$ were selected. The researchers discovered that the lower the solder ball volume, the greater the interfacial $\mathrm{Cu}_{6} \mathrm{Sn}_{5}$ grains and the $\mathrm{Cu}_{6} \mathrm{Sn}_{5} \mathrm{IMC}$ layer thickness. The dissolving of the $\mathrm{Cu}$ pad into molten solder was linked to the formation of the $\mathrm{Cu}_{6} \mathrm{Sn}_{5}$ IMC layer. $\mathrm{Cu}_{6} \mathrm{Sn}_{5}$ grains were finer interfacial due to the faster $\mathrm{Cu}$ dissolving rate in molten solder. Additionally, Ourdjini et al. [109] examined the Sn-Ag-Cu on electroless nickel/immersion gold (ENIG) surface finish with varied solder volumes $(300,500$, and $700 \mu \mathrm{m})$. The findings demonstrated that the volume of solder utilized has a substantial impact on the intermetallic thickness produced at solder joints. Also, the intermetallic generated in smaller-volume solders was found to be thicker compared to those produced in larger-volume solders. The solder bump volume, on the other hand, has no bearing on the intermetallic kinds or morphologies. Specifically, $(\mathrm{Cu}, \mathrm{Ni})_{6} \mathrm{Sn}_{5}$ and $(\mathrm{Ni}, \mathrm{Cu})_{3} \mathrm{Sn}_{4}$ were found in $\mathrm{Sn}-\mathrm{Ag}-\mathrm{Cu}$ solder joints.

On the other hand, Huang et al. [110] employed an Sn-3.0Ag-0.5Cu solder ball to prove the impact of solder volume on interfacial reaction. The bigger the interfacial $\mathrm{Cu}_{6} \mathrm{Sn}_{5}$ grains and the thicker the $\mathrm{Cu}_{6} \mathrm{Sn}_{5}$ IMC layer were proven to be, the smaller the solder ball volume. With rising reflow times, the $\mathrm{Cu}_{6} \mathrm{Sn}_{5}$ grains average diameter, the thickness of the $\mathrm{Cu}_{6} \mathrm{Sn}_{5} \mathrm{IMC}$ layer, and the consumed thickness of the $\mathrm{Cu}$ pad all improved.

\section{Conclusions}

In this review, we have summarized the causes that can impact the formation and growth of intermetallic compounds (IMCs), which are recognized to constitute an important role in joint structure. It can be concluded that:

(1) The effect of minor alloying elements on the primary intermetallic and interfacial IMC can be substantial. The microstructure of eutectic alloy may be changed by the addition of a small amount of a given alloying element to the bulk microstructure. The alloying elements added to the solder also can influence the formation and growth of IMCs. This can decrease or increase the IMC's growth/reaction rate and result in the formation of an extra reaction layer at the interface

(2) The IMC layer is considerably affected by the surface finishes material during soldering. The thickness and composition of IMCs also greatly affected by surface finish layers that formed by a process called dissolution, where some amount of the surface metallization dissolves into the molten solder, and the formation of IMCs differs depending on the surface finish.

(3) Different aging temperatures and time also influenced the thickness of interfacial intermetallic. Higher temperatures and longer aging times increase the IMC growth

(4) The average thickness of the intermetallic for low solder volume is thicker than for high solder volume solders. This was due to the fact the $\mathrm{Cu}$ concentration in the solder grew quicker in smaller solder balls than in bigger ones.

Author Contributions: Conceptualisation, methodology and writing, M.I.I.R.; supervision and resources, M.A.A.M.S.; data curation, review and editing, M.M.A.B.A., S.F.M.A., N.S.M.Z. and A.V.S.; validation and visualisation P.V. and A.R. This version of the work has been reviewed and approved by all authors. All authors have read and agreed to the published version of the manuscript.

Funding: Neutron tomography studies of geopolymer ceramic used for reinforcement materials in solder alloy for a robust electric/electronic solder joint under reference No: JPT.S (BPKI)2000/016/018/019(29).

Institutional Review Board Statement: Not applicable.

Informed Consent Statement: Not applicable.

Data Availability Statement: The data presented in this study are available on request from the corresponding author. 
Acknowledgments: This work was supported by Ministry of Higher Education, Malaysia on Project use of ISIS Neutron and Muon Source. The grant is funded by the UK Department of Business, Energy and Industrial Strategy (BEIS) and Malaysia and delivered by the British Council.

Conflicts of Interest: The authors declare no conflict of interest.

\section{References}

1. Hu, X.; Li, Y.; Liu, Y.; Min, Z. Developments of high strength Bi-containing Sn0.7Cu lead-free solder alloys prepared by directional solidification. J. Alloys Compd. 2015, 625, 241-250. [CrossRef]

2. Qiu, J.; Peng, Y.; Gao, P.; Li, C. Effect of Cu Content on Performance of Sn-Zn-Cu Lead-Free Solder Alloys Designed by Cluster-Plus-Glue-Atom Model. Materials 2021, 14, 2335. [CrossRef] [PubMed]

3. Bi, W.; Ju, G.; Lin, F. Interfacial IMC layer growth and tensile properties of low-silver Cu/SACBE/Cu solder joints. Solder. Surf. Mt. Technol. 2012, 24, 249-256. [CrossRef]

4. Sun, L.; Zhang, L. Properties and Microstructures of Sn-Ag-Cu-X Lead-Free Solder Joints in Electronic Packaging. Adv. Mater. Sci. Eng. 2015, 2015, 639028. [CrossRef]

5. Sayyadi, R.; Naffakh-Moosavy, H. The Role of Intermetallic Compounds in Controlling the Microstructural, Physical and Mechanical Properties of Cu-[Sn-Ag-Cu-Bi]-Cu Solder Joints. Sci. Rep. 2019, 9, 8389. [CrossRef]

6. Kotadia, H.R.; Howes, P.; Mannan, S. A review: On the development of low melting temperature Pb-free solders. Microelectron. Reliab. 2014, 54, 1253-1273. [CrossRef]

7. Nogita, K.; Read, J.; Nishimura, T.; Sweatman, K.; Suenaga, S.; Dahle, A.K. Microstructure Control in Sn-0.7 mass\%Cu Alloys. Mater. Trans. 2005, 46, 2419-2425. [CrossRef]

8. Gourlay, C.; Nogita, K.; McDonald, S.; Nishimura, T.; Sweatman, K.; Dahle, A. A rheological assessment of the effect of trace level $\mathrm{Ni}$ additions on the solidification of Sn-0.7Cu. Scr. Mater. 2006, 54, 1557-1562. [CrossRef]

9. Nogita, K.; McDonald, S.D.; Tsukamoto, H.; Read, J.; Suenaga, S.; Nishimura, T. Inhibiting Cracking of Interfacial Cu6Sn5 by Ni Additions to Sn-based Lead-free Solders. Trans. Jpn. Inst. Electron. Packag. 2009, 2, 46-54. [CrossRef]

10. Salleh, M.M.; McDonald, S.; Gourlay, C.; Belyakov, S.; Yasuda, H.; Nogita, K. Effect of Ni on the Formation and Growth of Primary Cu6Sn5 Intermetallics in Sn-0.7 wt.\%Cu Solder Pastes on Cu Substrates During the Soldering Process. J. Electron. Mater. 2015, 45, 154-163. [CrossRef]

11. Ventura, T.; Terzi, S.; Rappaz, M.; Dahle, A.K. Effects of Ni additions, trace elements and solidification kinetics on microstructure formation in Sn-0.7Cu solder. Acta Mater. 2011, 59, 4197-4206. [CrossRef]

12. Silva, B.L.; Cheung, N.; Garcia, A.; Spinelli, J.E. Thermal Parameters, Microstructure, and Mechanical Properties of Directionally Solidified Sn-0.7 wt.\%Cu Solder Alloys Containing 0 ppm to 1000 ppm Ni. J. Electron. Mater. 2013, 42, 179-191. [CrossRef]

13. Gumaan, M.S.; Shalaby, R.M.; Yousef, M.K.M.; Ali, E.A.; Abdel-Hady, E.E. Nickel effects on the structural and some physical properties of the eutectic Sn-Ag lead-free solder alloy. Solder. Surf. Mt. Technol. 2019, 31, 40-51. [CrossRef]

14. Xian, J.W.; Belyakov, S.A.; Gourlay, C.M. Controlling Bulk Cu6Sn5 Nucleation in Sn0.7Cu/Cu Joints with Al Micro-alloying. J. Electron. Mater. 2015, 45, 69-78. [CrossRef]

15. Wang, T.; Zhou, P.; Cao, F.; Kang, H.; Chen, Z.; Fu, Y.; Xiao, T.; Huang, W.; Yuan, Q. Growth behavior of Cu6Sn5 in Sn-6.5 Cu solders under DC considering trace Al: In situ observation. Intermetallics 2015, 58, 84-90. [CrossRef]

16. Yang, L.; Zhang, Y.; Du, C.; Dai, J.; Zhang, N. Effect of aluminum concentration on the microstructure and mechanical properties of $\mathrm{Sn}-\mathrm{Cu}-\mathrm{Al}$ solder alloy. Microelectron. Reliab. 2015, 55, 596-601. [CrossRef]

17. Ma, X.; Qian, Y.; Yoshida, F. Effect of La on the Cu-Sn intermetallic compound (IMC) growth and solder joint reliability. J. Alloys Compd. 2002, 334, 224-227. [CrossRef]

18. McDonald, S.; Nogita, K.; Read, J.; Ventura, T.; Nishimura, T. Influence of Composition on the Morphology of Primary Cu ${ }_{6} \mathrm{Sn}_{5}$ in Sn-4Cu Alloys. J. Electron. Mater. 2013, 42, 256-262. [CrossRef]

19. Reeve, K.N.; Anderson, I.E.; Handwerker, C.A. Nucleation and Growth of Cu-Al Intermetallics in Al-Modified Sn-Cu and Sn-Ag-Cu Lead-Free Solder Alloys. J. Electron. Mater. 2015, 44, 842-866. [CrossRef]

20. Wu, C.M.L.; Yu, D.Q.; Law, C.M.T.; Wang, L. Microstructure and Mechanical Properties of New Lead-Free Sn-Cu-RE Solder Alloys. J. Electron. Mater. 2002, 31, 928-932. [CrossRef]

21. Zeng, G.; McDonald, S.; Gu, Q.; Terada, Y.; Uesugi, K.; Yasuda, H.; Nogita, K. The influence of Ni and Zn additions on microstructure and phase transformations in $\mathrm{Sn}-0.7 \mathrm{Cu} / \mathrm{Cu}$ solder joints. Acta Mater. 2015, 83, 357-371. [CrossRef]

22. Zeng, G.; McDonald, S.D.; Gourlay, C.M.; Uesugi, K.; Terada, Y.; Yasuda, H.; Nogita, K. Solidification of Sn-0.7Cu-0.15Zn Solder: In Situ Observation. Met. Mater. Trans. A 2014, 45A, 918-926. [CrossRef]

23. Laurila, T.; Vuorinen, V.; Kivilahti, J.K. Interfacial reactions between lead-free solders and common base materials. Mater. Sci. Eng. R Rep. 2005, 49, 1-60. [CrossRef]

24. Nogita, K. Stabilisation of Cu6Sn5 by Ni in Sn-0.7Cu-0.05Ni lead-free solder alloys. Intermetallics 2010, 18, 145-149. [CrossRef]

25. $\mathrm{Hu}, \mathrm{X}$.; Qiu, H.; Jiang, X. Effect of Ni addition into the $\mathrm{Cu}$ substrate on the interfacial IMC growth during the liquid-state reaction with Sn-58Bi solder. J. Mater. Sci. Mater. Electron. 2018, 30, 1907-1918. [CrossRef]

26. Yang, L.; Zhang, Y.; Dai, J.; Jing, Y.; Ge, J.; Zhang, N. Microstructure, interfacial IMC and mechanical properties of Sn-0.7Cu-xAl $(x=0-0.075)$ lead-free solder alloy. Mater. Des. 2015, 67, 209-216. [CrossRef] 
27. Liu, P.; Yao, P.; Liu, J. Evolutions of the interface and shear strength between SnAgCu-xNi solder and Cu substrate during isothermal aging at $150^{\circ} \mathrm{C}$. J. Alloys Compd. 2009, 486, 474-479. [CrossRef]

28. Yao, P.; Liu, P.; Liu, J. Effects of multiple reflows on intermetallic morphology and shear strength of SnAgCu-xNi composite solder joints on electrolytic Ni/Au metallized substrate. J. Alloys Compd. 2008, 462, 73-79. [CrossRef]

29. Nagy, E.; Kristaly, F.; Gyenes, A.; Gacsi, Z. Investigation of Intermetallic Compounds In Sn-Cu-Ni Lead-Free Solders. Arch. Met. Mater. 2015, 60, 1511-1515. [CrossRef]

30. Rizvi, M.; Bailey, C.; Chan, Y.; Islam, M.; Lu, H. Effect of adding 0.3wt \% Ni into the Sn-0.7wt $\%$ Cu solder: Part II. Growth of intermetallic layer with $\mathrm{Cu}$ during wetting and aging. J. Alloys Compd. 2007, 438, 122-128. [CrossRef]

31. Nishikawa, H.; Komatsu, A.; Takemoto, T. Morphology and Pull Strength of Sn-Ag(-Co) Solder Joint with Copper Pad. J. Electron. Mater. 2007, 36, 1137-1143. [CrossRef]

32. Yen, Y.-W.; Chiang, Y.-C.; Jao, C.-C.; Liaw, D.-W.; Lo, S.-C.; Lee, C. Interfacial reactions and mechanical properties between Sn-4.0 Ag-0.5 Cu and Sn-4.0 Ag-0.5 Cu-0.05 Ni-0.01 Ge lead-free solders with the Au/Ni/Cu substrate. J. Alloys Compd. 2011, 509, 4595-4602. [CrossRef]

33. Wang, C.-H.; Shen, H.-T. Effects of Ni addition on the interfacial reactions between $\mathrm{Sn}-\mathrm{Cu}$ solders and Ni substrate. Intermetallics 2010, 18, 616-622. [CrossRef]

34. Zou, H.; Zhang, Z. Effect of Zn Addition on Interfacial Reactions between Sn-4Ag Solder and Ag Substrates. J. Electron. Mater. 2008, 37, 1119-1129. [CrossRef]

35. Chan, Y.H.; Arafat, M.M.; Haseeb, A.S.M.A. Effects of reflow on the interfacial characteristics between Zn nanoparticles containing Sn-3.8Ag-0.7Cu solder and copper substrate. Solder. Surf. Mt. Technol. 2013, 25, 91-98. [CrossRef]

36. Zhang, L.; Han, J.g.; He, C.w.; Guo, Y.h. Effect of Zn on properties and microstructure of SnAgCu alloy. J. Mater. Sci. Mater. Electron. 2012, 23, 1950-1956. [CrossRef]

37. Mahdavifard, M.H.; Sabri, M.F.M.; Shnawah, D.A.; Said, S.M.; Badruddin, I.A.; Rozali, S. The effect of iron and bismuth addition on the microstructural, mechanical, and thermal properties of Sn-1Ag-0.5Cu solder alloy. Microelectron. Reliab. 2015, 55, 1886-1890. [CrossRef]

38. Zeng, G.; Xue, S.; Zhang, L.; Gao, L.; Dai, W.; Luo, J. A review on the interfacial intermetallic compounds between Sn-Ag-Cu based solders and substrates. J. Mater. Sci. Mater. Electron. 2010, 21, 421-440. [CrossRef]

39. Shalaby, R.M. Indium, chromium and nickel-modified eutectic Sn-0.7 wt $\% \mathrm{Cu}$ lead-free solder rapidly solidified from molten state. J. Mater. Sci. Mater. Electron. 2015, 26, 6625-6632. [CrossRef]

40. Li, L.F.; Cheng, Y.K.; Xu, G.L.; Wang, E.Z.; Zhang, Z.H.; Wang, H. Effects of indium addition on properties and wettability of Sn-0.7Cu-0.2Ni lead-free solders. Mater. Des. 2014, 64, 15-20. [CrossRef]

41. Lee, H.-T.; Lee, F.-F.; Hong, T.-F.; Chen, H.-W. Effect of in addition on Sn-Ag-Sb lead-free solder system. IEEE 2008, 191-194. [CrossRef]

42. Li, G.; Shi, Y.; Hao, H.; Xia, Z.; Lei, Y.; Guo, F. Effect of phosphorus element on the comprehensive properties of Sn-Cu lead-free solder. J. Alloys Compd. 2010, 491, 382-385. [CrossRef]

43. Xian, J.W.; Belyakov, S.A.; Britton, T.B.; Gourlay, C.M. Heterogeneous nucleation of Cu6Sn5 in Sn-Cu-Al solders. J. Alloys Compd. 2015, 619, 345-355. [CrossRef]

44. Ma, L.; Tai, F.; Xu, G.; Guo, F.; Wang, X. Effects of Processing and Amount of Co Addition on Shear Strength and Microstructual Development in the Sn-3.0Ag-0.5Cu Solder Joint. J. Electron. Mater. 2011, 40, 1416-1421. [CrossRef]

45. Luo, D.-X.; Xue, S.-B.; Li, Z.-Q. Effects of Ga addition on microstructure and properties of Sn-0.5Ag-0.7Cu solder. J. Mater. Sci. Mater. Electron. 2014, 25, 3566-3571. [CrossRef]

46. Gao, L.; Xue, S.; Zhang, L.; Sheng, Z.; Zeng, G.; Ji, F. Effects of trace rare earth Nd addition on microstructure and properties of SnAgCu solder. J. Mater. Sci. Mater. Electron. 2010, 21, 643-648. [CrossRef]

47. Dudek, M.A.; Sidhu, R.S.; Chawla, N.; Renavikar, M. Microstructure and mechanical behavior of novel rare earth-containing Pb-Free solders. J. Electron. Mater. 2006, 35, 2088-2097. [CrossRef]

48. Zhang, L.; Xue, S.B.; Zeng, G.; Gao, L.L.; Ye, H. Interface reaction between SnAgCu/SnAgCuCe solders and Cu substrate subjected to thermal cycling and isothermal aging. J. Alloys Compd. 2012, 510, 38-45. [CrossRef]

49. Liu, X.; Huang, M.; Zhao, N.; Wang, L. Liquid-state and solid-state interfacial reactions between Sn-Ag-Cu-Fe composite solders and Cu substrate. J. Mater. Sci. Mater. Electron. 2014, 25, 328-337. [CrossRef]

50. Haseeb, A.S.M.A.; Leng, T.S. Effects of Co nanoparticle addition to Sn-3.8Ag-0.7Cu solder on interfacial structure after reflow and ageing. Intermetallics 2011, 19, 707-712. [CrossRef]

51. Haseeb, A.; Arafat, M.; Johan, M.R. Stability of molybdenum nanoparticles in Sn-3.8Ag-0.7Cu solder during multiple reflow and their influence on interfacial intermetallic compounds. Mater. Charact. 2012, 64, 27-35. [CrossRef]

52. Rizvi, M.; Chan, Y.; Bailey, C.; Lu, H.; Islam, M. Effect of adding $1 w t \%$ Bi into the Sn-2.8Ag-0.5Cu solder alloy on the intermetallic formations with Cu-substrate during soldering and isothermal aging. J. Alloys Compd. 2006, 407, 208-214. [CrossRef]

53. Koo, J.; Lee, C.; Hong, S.J.; Kim, K.-S.; Lee, H.M. Microstructural discovery of Al addition on Sn-0.5Cu-based Pb-free solder design. J. Alloys Compd. 2015, 650, 106-115. [CrossRef]

54. Ramli, M.; Salleh, M.M.; Yasuda, H.; Chaiprapa, J.; Nogita, K. The effect of Bi on the microstructure, electrical, wettability and mechanical properties of $\mathrm{Sn}-0.7 \mathrm{Cu}-0.05 \mathrm{Ni}$ alloys for high strength soldering. Mater. Des. 2020, 186, 108281. [CrossRef] 
55. Shen, C.; Hai, Z.; Zhao, C.; Zhang, J.; Evans, J.L.; Bozack, M.J.; Suhling, J.C. Packaging Reliability Effect of ENIG and ENEPIG Surface Finishes in Board Level Thermal Test under Long-Term Aging and Cycling. Materials 2017, 10, 451. [CrossRef] [PubMed]

56. Ho, C.; Yang, S.; Lee, P.; Lee, C.; Chen, C.; Kuo, T. IMC microstructure modification and mechanical reinforcement of Sn$\mathrm{Ag}-\mathrm{Cu} / \mathrm{Cu}$ microelectronic joints through an advanced surface finish technique. J. Mater. Res. Technol. 2021, 11, 1895-1910. [CrossRef]

57. Nogita, K.; Nishimura, T. Nickel-stabilized hexagonal (Cu,Ni)6Sn5 in Sn-Cu-Ni lead-free solder alloys. Scr. Mater. 2008, 59, 191-194. [CrossRef]

58. Liu, S.; Yang, C.; Ling, H.; Hu, A.; Hang, T.; Gao, L.; Li, M. Inhibiting effects of the Ni barrier layer on the growth of porous Cu3Sn in 10- $\mu \mathrm{m}$ microbumps. J. Mater. Sci. Mater. Electron. 2021, 32, 17655-17661. [CrossRef]

59. Seo, W. Effect of Electroless Ni Plating Bath Conditions on the Impact Reliability of Sn-Ag-Cu Solder Joints. Ph.D. Thesis, Hanyang University, Seoul, Korea, 2020.

60. Yoon, J.-W.; Noh, B.-I.; Jung, S.-B. Effects of third element and surface finish on interfacial reactions of $\mathrm{Sn}-\mathrm{Ag}-\mathrm{xCu}(\mathrm{or} \mathrm{Ni}) /(\mathrm{Cu}$ or ENIG) solder joints. J. Alloys Compd. 2010, 506, 331-337. [CrossRef]

61. Zheng, Y.; Hillman, C.; McCluskey, P. Effect of PWB Plating on the Microstructure and Reliability of SnAgCu Solder Joints. In Proceedings of the AESF SUR/FIN 2002: Annual International Technical Conference, Chicago, IL, USA, 24-17 June 2002; pp. 24-27.

62. Ourdjini, A.; Hanim, M.A.A.; Aisha, I.S.R.; Chin, Y.T. Effect of surface finish metallurgy on intermetallic compounds during soldering with tin-silver-copper solders. In Proceedings of the 2008 33rd IEEE/CPMT International Electronics Manufacturing Technology Conference (IEMT); Institute of Electrical and Electronics Engineers (IEEE), Penang, Malaysia, 4-6 November 2008; pp. $1-4$

63. Ha, S.-S.; Park, J.; Jung, S.-B. Effect of Pd Addition in ENIG Surface Finish on Drop Reliability of Sn-Ag-Cu Solder Joint. Mater. Trans. 2011, 52, 1553-1559. [CrossRef]

64. Kim, Y.M.; Park, J.-Y. Effect of Pd Thickness on the Interfacial Reaction and Shear Strength in Solder Joints between Sn-3.0Ag-0.5Cu Solder and Electroless Nickel/Electroless Palladium/Immersion Gold (ENEPIG) Surface Finish. J. Electron. Mater. 2012, 41, 763-773. [CrossRef]

65. Yoon, J.-W.; Kim, S.-W.; Jung, S.-B. Effect of reflow time on interfacial reaction and shear strength of Sn-0.7Cu solder/Cu and electroless Ni-P BGA joints. J. Alloys Compd. 2004, 385, 192-198. [CrossRef]

66. Yin, H.G.; Shen, J.; Tang, Q. Wetting of Sn-O 7Cu Solder Alloy on Different Substrates at Different Temperatures. In Proceedings of the International Conference on Electronic Packaging Technology \& High Density Packaging, Guilin, China, 13-16 August 2012; pp. 280-284.

67. Aisha, I.S.R.; Ourdjini, A.; Astuty, A.; Saliza, O. Effect of Surface Finish On Intermetallic Compound Formation During Soldering With Ni-Doped Solders. Solid State Sci. Technol. 2011, 19, 319-329.

68. Yoon, J.-W.; Noh, B.-I.; Jung, S.-B. Comparative Study of ENIG and ENEPIG as Surface Finishes for a Sn-Ag-Cu Solder Joint. J. Electron. Mater. 2011, 40, 1950-1955. [CrossRef]

69. Sun, P.; Andersson, C.; Wei, X.; Cheng, Z.; Shangguan, D.; Liu, J. Intermetallic compound formation in Sn-Co-Cu, Sn-Ag-Cu and eutectic $\mathrm{Sn}-\mathrm{Cu}$ solder joints on electroless $\mathrm{Ni}(\mathrm{P})$ immersion Au surface finish after reflow soldering. Mater. Sci. Eng. B 2006, 135, 134-140. [CrossRef]

70. Adawiyah, M.R.; Azlina, O.S. Comparative study on the isothermal aging of bare Cu and ENImAg surface finish for Sn-Ag-Cu solder joints. J. Alloys Compd. 2018, 740, 958-966. [CrossRef]

71. Vidyatharran, K.; Hanim, M.A.; Dele-Afolabi, T.; Matori, K.; Azlina, O.S. Microstructural and shear strength properties of GNSs-reinforced Sn-1.0Ag-0.5Cu (SAC105) composite solder interconnects on plain Cu and ENIAg surface finish. J. Mater. Res. Technol. 2021, 15, 2497-2506. [CrossRef]

72. Ab Rahim, R.A.A.; Zulkifli, M.N.; Mohd Afdzaluddin, A.; Shyong, K.S. Effect of isothermal aging and copper substrate roughness on the SAC305 solder joint intermetallic layer growth of high temperature storage (HTS). Sains Malays. 2020, 49, 3045-3054. [CrossRef]

73. Yoon, J.-W.; Jung, S.-B. Effect of surface finish on interfacial reactions of $\mathrm{Cu} / \mathrm{Sn}-\mathrm{Ag}-\mathrm{Cu} / \mathrm{Cu}(\mathrm{ENIG})$ sandwich solder joints. J. Alloys Compd. 2008, 448, 177-184. [CrossRef]

74. Seo, W.; Kim, K.-H.; Kim, Y.-H.; Yoo, S. Effect of Ni-P Plating Temperature on Growth of Interfacial Intermetallic Compound in Electroless Nickel Immersion Gold/Sn-Ag-Cu Solder Joints. J. Electron. Mater. 2017, 47, 110-116. [CrossRef]

75. Su, S.; Jian, M.; Hamasha, S. Effects of Surface Finish on the Shear Fatigue of SAC-Based Solder Alloys. IEEE Trans. Compon. Packag. Manuf. Technol. 2019, 10, 457-466. [CrossRef]

76. Amli, S.F.N.M.; Salleh, M.A.A.M.; Ramli, M.I.I.; Razak, N.R.A.; Yasuda, H.; Chaiprapa, J.; Nogita, K. Effects of Surface Finish on Sn-3.0Ag-0.5Cu Solder Joint Microstructure and Strength. J. Electron. Mater. 2021, 50, 855-868. [CrossRef]

77. Azlina, O.S.; Ourdjini, A.; Ibrahim, M.H.I.; Sallehuddin, Y.M. Comparison between SAC405 Lead-Free Solders and EN(P)EPIG and EN(B)EPIG Surface Finishes. Appl. Mech. Mater. 2015, 773, 232-236. [CrossRef]

78. Amli, S.F.M.; Salleh, M.A.A.M.; Said, R.M.; Razak, N.R.A.; Wahab, J.A.; Ramli, M.I.I. Effect of surface finish on the wettability and electrical resistivity of Sn-3.0 Ag-0.5 Cu solder. In IOP Conference Series: Materials Science and Engineering; IOP Publishing: Bristol, UK, 2019. 
79. Akkara, F.; Abueed, M.; Rababah, M.; Zhao, C.; Su, S.; Suhling, J.; Evans, J. Effect of surface finish and high bi solder alloy on component reliability in thermal cycling. In Proceedings of the 2018 IEEE 68th Electronic Components and Technology Conference (ECTC) IEEE, San Diego, CA, USA, 29 May-1 June 2018.

80. Wu, C.M.L.; Yu, D.Q.; Law, C.M.T.; Wang, L. Properties of lead-free solder alloys with rare earth element additions. Mater. Sci. Eng. R Rep. 2004, 44, 1-44. [CrossRef]

81. Sivakumar, P.; O'Donnell, K.; Cho, J. Effects of bismuth and nickel on the microstructure evolution of Sn-Ag-Cu (SAC)-based solders. Mater. Today Commun. 2021, 26, 101787. [CrossRef]

82. Mookam, N.; Kanlayasiri, K. Evolution of Intermetallic Compounds between Sn-0.3Ag-0.7Cu Low-silver Lead-free Solder and Cu Substrate during Thermal Aging. J. Mater. Sci. Technol. 2012, 28, 53-59. [CrossRef]

83. Noor, E.E.M.; Abdullah, M.M.A.B. Effect of Thermal Aging on the Interfacial of Sn-Zn and Sn-Zn-Bi Solders Joint on Cu Substrate. Key Eng. Mater. 2016, 700, 113-122

84. Chuang, T.-H.; Yen, S.-F.; Wu, H.-M. Intermetallic formation in Sn3Ag0.5Cu and Sn3Ag0.5Cu0.06Ni0.01Ge solder BGA packages with immersion Ag surface finish. J. Electron. Mater. 2006, 35, 310-318. [CrossRef]

85. Yoon, J.-W.; Kim, S.-W.; Jung, S.-B. Interfacial reaction and mechanical properties of eutectic Sn-0.7Cu/Ni BGA solder joints during isothermal long-term aging. J. Alloys Compd. 2005, 391, 82-89. [CrossRef]

86. Hodulova, E.; Palcut, M.; Lechovic, E.; Simekova, B.; Ulrich, K. Kinetics of intermetallic phase formation at the interface of Sn-Ag-Cu-X (X = Bi, In) solders with Cu substrate. J. Alloys Compd. 2011, 509, 7052-7059. [CrossRef]

87. Lejuste, C.; Hodaj, F.; Petit, L. Solid state interaction between a Sn-Ag-Cu-In solder alloy and Cu substrate. Intermetallics 2013, 36, 102-108. [CrossRef]

88. Wu, A.T.; Chen, M.-H.; Siao, C.-N. The Effects of Solid-State Aging on the Intermetallic Compounds of Sn-Ag-Bi-In Solders on Cu Substrates. J. Electron. Mater. 2008, 38, 252-256. [CrossRef]

89. Kanlayasiri, K.; Sukpimai, K. Effects of indium on the intermetallic layer between low-Ag SAC0307-xIn lead-free solders and Cu substrate. J. Alloys Compd. 2016, 668, 169-175. [CrossRef]

90. Wang, F.; Ma, X.; Qian, Y. Improvement of microstructure and interface structure of eutectic Sn-0.7Cu solder with small amount of $\mathrm{Zn}$ addition. Scr. Mater. 2005, 55, 699-702. [CrossRef]

91. Wang, Y.; Lin, Y.; Tu, C.; Kao, C. Effects of minor Fe, Co, and Ni additions on the reaction between SnAgCu solder and Cu. J. Alloys Compd. 2009, 478, 121-127. [CrossRef]

92. Dong, W.; Shi, Y.; Xia, Z.; Lei, Y.; Guo, F. Effects of Trace Amounts of Rare Earth Additions on Microstructure and Properties of Sn-Bi-Based Solder Alloy. J. Electron. Mater. 2008, 37, 982-991. [CrossRef]

93. Song, Q.; Yang, W.; Li, Y.; Mao, J.; Qin, W.; Zhan, Y. Interfacial reaction and mechanical properties of Sn58Bi-XCr solder joints under isothermal aging conditions. Vacuum 2021, 194, 110559. [CrossRef]

94. Liu, Y.; Ren, B.; Xue, Y.; Zhou, M.; Cao, R.; Chen, P.; Zeng, X. Microstructure and mechanical behavior of SnBi-xAg and SnBi-xAg@P-Cu solder joints during isothermal aging. Microelectron. Reliab. 2021, 127, 114388. [CrossRef]

95. Tang, Y.; Li, G.Y.; Chen, D.Q.; Pan, Y.C. Influence of $\mathrm{TiO}_{2}$ nanoparticles on $\mathrm{IMC}_{\mathrm{M}}$ growth in $\mathrm{Sn}-3.0 \mathrm{Ag}-0.5 \mathrm{Cu}-\mathrm{xTiO} 2$ solder joints during isothermal aging process. J. Mater. Sci. Mater. Electron. 2014, 25, 981-991. [CrossRef]

96. Yang, L.; Quan, S.; Liu, C.; Shi, G. Aging resistance of the Sn-Ag-Cu solder joints doped with Mo nanoparticles. Mater. Lett. 2019, 253, 191-194. [CrossRef]

97. Zeng, G.; McDonald, S.; Mu, D.; Terada, Y.; Yasuda, H.; Gu, Q.; Salleh, M.M.; Nogita, K. The influence of ageing on the stabilisation of interfacial $(\mathrm{Cu}, \mathrm{Ni})_{6}(\mathrm{Sn}, \mathrm{Zn})_{5}$ and $(\mathrm{Cu}, \mathrm{Au}, \mathrm{Ni}) 6 \mathrm{Sn} 5$ intermetallics in Pb-free Ball Grid Array (BGA) solder joints. J. Alloys Compd. 2016, 685, 471-482. [CrossRef]

98. Hasnine, M.; Vahora, N. Microstructural and mechanical behavior of $\mathrm{SnCu}-\mathrm{Ge}$ solder alloy subjected to high temperature storage. J. Mater. Sci. Mater. Electron. 2018, 29, 8904-8913. [CrossRef]

99. Tang, Y.; Luo, S.; Li, Z.; Hou, C.; Li, G. Morphological Evolution and Growth Kinetics of Interfacial $\mathrm{Cu}_{6} \mathrm{Sn}_{5}$ and $_{\mathrm{Cu}} \mathrm{Sn} \mathrm{Layers} \mathrm{in}$ Low-Ag Sn-0.3Ag-0.7Cu-xMn/Cu Solder Joints During Isothermal Ageing. J. Electron. Mater. 2018, 47, 5913-5929. [CrossRef]

100. Mahdavifard, M.H.; Sabri, M.F.M.; Said, S.M.; Rozali, S. High stability and aging resistance Sn-1Ag-0.5Cu solder alloy by Fe and Bi minor alloying. Microelectron. Eng. 2019, 208, 29-38. [CrossRef]

101. Wang, Y. Effects of surface diffusion and solder volume on porous-type Cu3Sn in Cu/Sn/Cu microjoints. Mater. Chem. Phys. 2021, 275, 125307. [CrossRef]

102. Park, H.-P.; Seo, G.; Kim, S.; Kim, Y.-H. Effects of Solder Volume and Reflow Conditions on Self-Alignment Accuracy for Fan-Out Package Applications. J. Electron. Mater. 2018, 47, 133-141. [CrossRef]

103. Sriperumbudur, S.S.; Meilunas, M.; Anselm, M. Solder paste volume effects on assembly yield and reliability for bottom terminated components. Solder. Surf. Mt. Technol. 2017, 29, 99-109. [CrossRef]

104. Wang, S.; Yao, Y.; Long, X. Critical Review of Size Effects on Microstructure and Mechanical Properties of Solder Joints for Electronic Packaging. Appl. Sci. 2019, 9, 227. [CrossRef]

105. Yang, S.C.; Chang, C.C.; Tsai, M.H.; Kao, C.R. Effect of $\mathrm{Cu}$ concentration, solder volume, and temperature on the reaction between SnAgCu solders and Ni. J. Alloys Compd. 2010, 499, 149-153. [CrossRef]

106. Chang, C.; Lin, Y.; Wang, Y.; Kao, C. The effects of solder volume and Cu concentration on the consumption rate of Cu pad during reflow soldering. J. Alloys Compd. 2010, 492, 99-104. [CrossRef] 
107. Azlina, O.S.; Ourdjini, A.; Amrin, A.; Siti Rabiatull Aisha, I. Effect of Solder Volume on Interfacial Reaction between SAC405 Solders and EN (B) EPIG Surface Finish. In Advanced Materials Research. Trans. Tech. Publ. 2014, 845, 76-80.

108. Liu, L.; Huang, M.; Yang, F.; Liu, T. Effect of solder volume on interfacial reaction between Sn-3Ag-0.5Cu solder ball and Cu Pad after multiple reflows. In Proceedings of the 2010 11th International Conference on Electronic Packaging Technology \& High Density Packaging; Institute of Electrical and Electronics Engineers (IEEE), Shanghai, China, 8-11 August 2011; pp. 1-6.

109. Ourdjini, A.; Hanim, M.A.; Koh, S.J.; Aisha, I.S.; Tan, K.; Chin, Y. Effect of Solder Volume on Interfacial Reactions between Eutectic $\mathrm{Sn}-\mathrm{Pb}$ and $\mathrm{Sn}-\mathrm{Ag}-\mathrm{Cu}$ Solders and $\mathrm{Ni}(\mathrm{P})$-Au Surface Finish. In Proceedings of the 2006 Thirty-First IEEE/CPMT International Electronics Manufacturing Technology Symposium; Institute of Electrical and Electronics Engineers (IEEE), Petaling Yaya, Malaysia, 8-10 November 2006; pp. 437-442.

110. Huang, M.; Yang, F.; Zhao, N.; Liu, X. (Invited) Solder Volume Effect on Interfacial Reaction between Sn-3.0Ag-0.5Cu Solder Balls and Cu Substrates-Experiment and Simulation. ECS Trans. 2013, 52, 753-758. [CrossRef] 